\title{
Monsters and the case of L. Joseph: André Feil's thesis on the origin of the Klippel-Feil syndrome and a social transformation of medicine
}

\author{
Evgenii Belykh, MD, ${ }^{1,2}$ Kashif Malik, BS, ${ }^{3}$ Isabelle Simoneau, MD, ${ }^{4}$ Kaan Yagmurlu, MD, ${ }^{1}$ \\ Ting Lei, MD, ${ }^{1}$ Daniel D. Cavalcanti, MD, ${ }^{1}$ Vadim A. Byvaltsev, MD, PhD, ${ }^{2}$ Nicholas Theodore, MD, ${ }^{1}$ \\ and Mark C. Preul, MD'
}

'Department of Neurosurgery, Barrow Neurological Institute, St. Joseph's Hospital and Medical Center, Phoenix; ${ }^{3}$ University of Arizona College of Medicine, Tucson; ${ }^{4}$ Valley Anesthesiology Consultants, Phoenix, Arizona; and ${ }^{2}$ rkutsk Scientific Center of Surgery and Traumatology, Irkutsk, Russia

\begin{abstract}
André Feil (1884-1955) was a French physician best recognized for his description, coauthored with Maurice Klippel, of patients with congenital fusion of cervical vertebrae, a condition currently known as Klippel-Feil syndrome. However, little is known about his background aside from the fact that he was a student of Klippel and a physician who took a keen interest in describing congenital anomalies. Despite the relative lack of information on Feil, his contributions to the fields of spinal disease and teratology extended far beyond science to play an integral role in changing the misguided perception shrouding patients with disfigurements, defects, deformities, and so-called monstrous births. In particular, Feil's 1919 medical school thesis on cervical abnormalities was a critical publication in defying long-held theory and opinion that human "monstrosities," anomalies, developmental abnormalities, and altered congenital physicality were a consequence of sinful behavior or a reversion to a primitive state. Indeed, his thesis on a spinal deformity centering on his patient, L. Joseph, was at the vanguard for a new view of a patient as nothing less than fully human, no matter his or her physicality or appearance.
\end{abstract}

http://thejns.org/doi/abs/10.3171/2016.3.FOCUS15488

KEY WORDS André Feil; history of neurosurgery; Klippel-Feil syndrome; Maurice Klippel; monsters; physical deformity; spinal ankyloses; spinal fusion; spine deformity

$\Lambda$ NDRÉ Feil (1884-1955) ${ }^{73}$ (Fig. 1) was a French physician best recognized for his description, coauthored with Maurice Klippel (1858-1942), of patients with congenital fusion of cervical vertebrae, a condition currently known as Klippel-Feil syndrome. However, little is known about his background aside from the fact that he was a student of Klippel and a physician who took a keen interest in describing congenital anomalies. Despite the relative paucity of biographical information on Feil, his contributions to the fields of spinal disease and teratology extended far beyond science, playing an integral role in changing misguided perceptions shrouding patients with disfigurements, defects, deformities, and so-called monstrous births. In particular, Feil's 1919 medical school thesis on cervical abnormalities was a critical publication in defying long-held theory and opinion that human "monstrosities," anomalies, developmental abnormalities, and altered congenital physicality were a con- sequence of sinful behavior or a reversion to a primitive state. In fact, his thesis on a spinal deformity centering on his patient, L. Joseph, was at the vanguard for a new view of the patient as nothing less than fully human, no matter the person's physicality or appearance. A full appreciation of the far-reaching implications of Feil's work requires us to present this thesis within the context of an overview of the philosophical history of human deformity and monstrosity leading up to the early 20th century.

\section{Legends of Headless Monsters}

One of the earliest references concerning cephalic abnormalities was a description of "headless monsters." The first mention regarding the "headless ones that have eyes in their chests" was by Herodotus in "The History" (450 $\mathrm{BCE}$, possibly in reference to fictitious inhabitants of Libya. ${ }^{35}$ Later the Blemmyes, members of a nomadic Nubian 

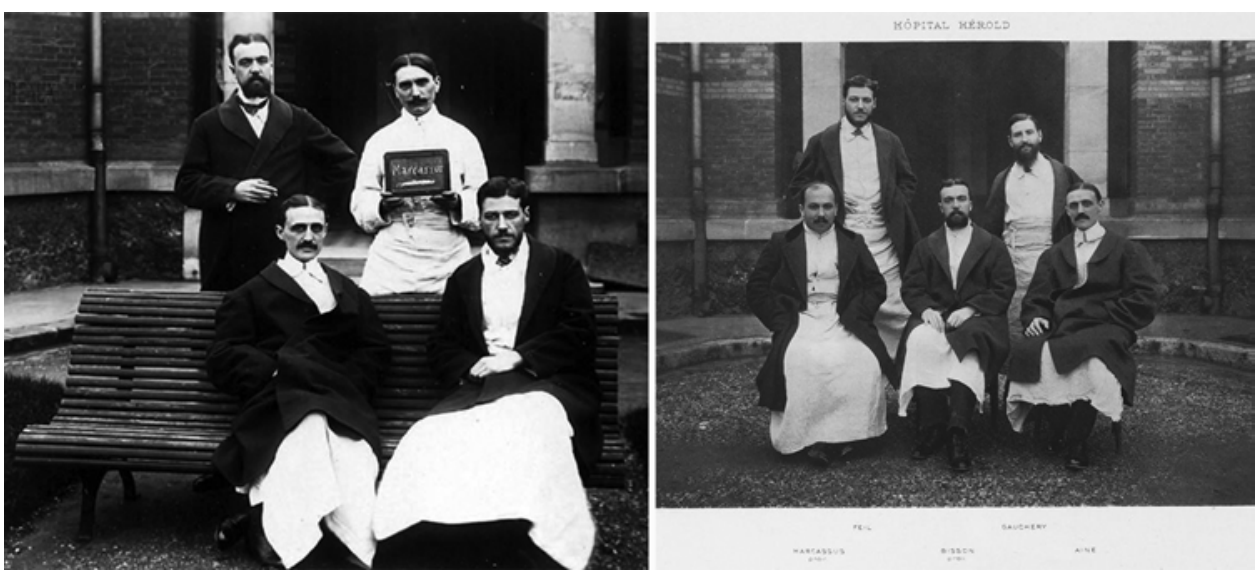

FIG. 1. Left: Photograph from the album of 1912-1913 medical interns graduating from the Hôpital Hérold. Feil is seated at the right. Right: Photograph from an internship album of the 1913 graduates of Paris hospitals. Feil is the tall man standing in the back on the left.

tribal kingdom (600 BCE to 8th century), described as a tribe that apparently fought the Romans, were fictionalized as a legendary race of acephalous monsters with eyes and mouths on their chests (Fig. 2).$^{58}$ What had led to the mystification of Blemmyes as "headless creatures" is unknown. Hypotheses have been postulated in an effort to explain the myths of headless humans, including those in tales told by Greek and Roman travelers about ceremonial tribal masks; these are possibly references to ornamented shields used for defense by the tribe that, from a distance, made those who wielded the shields appear headless, or these may be translations of local beliefs supported by Herodotus. ${ }^{3}$ The transformation of Blemmyes into monsters is found in communications of the Roman geographer, Pomponius Mela, around 15 to $60 \mathrm{BCE} .{ }^{59}$ References to headless people are also found in writings by 5 th-century writer Martianus Capella (about 410-420 CE) ${ }^{13}$ and 7thcentury Spanish Archbishop Isidore of Seville (560-636 CE). ${ }^{36}$ Seven-foot-high headless creatures continued to be discussed in 10th-century literature. ${ }^{37}$

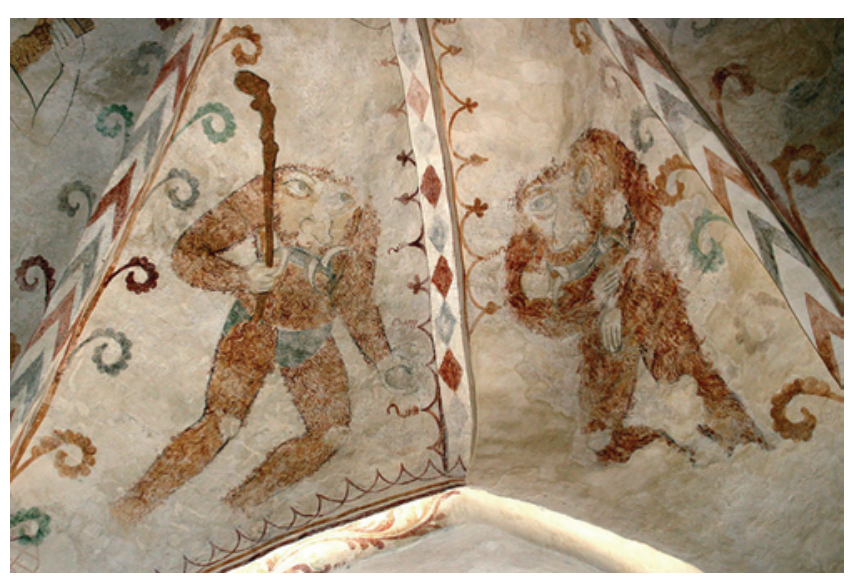

FIG. 2. A 1511 Gothic fresco from the western arch in the nave of Dalbyneder Church depicting two Blemmyes, who symbolize avarice and gluttony, 2 of the 7 Catholic mortal sins. Dalbyneder Sogn, Gjerlev Herred, Randers Amt, Denmark.
Discussions concerning these physically anomalous tribes in early Christian literature, including the headless Blemmyes, included the most crucial question of whether they belonged to the human race. There is no clear answer to this question in the literature, but the general tendency was to recognize them as humans. However, in the GrecoRoman view, these depictions were viewed as deviating too far from the characteristic features of the human race to be described by the epithet "men."27

During this period of uncertainty concerning humans with varying appearances, the Christian literature played a fundamental role in creating what would become a long-lasting and relatively inverse pejorative association between anatomical differences and morality. Monstrous races were thought to have originated not from Adam but from Cain. Humanoid races, which were not considered fully human, as well as creatures that have little to do with men, were considered the offspring of Cain. The appearance of such people was thought to be the consequence of a curse that led to moral and then physical degradation and to separation of the descendants of Cain. Ham, one of the sons of Noah, also began to be associated with the origins of such human decay or of being considered less than fully human after he was cursed by Noah. Humans with the head of a horse, two heads, or two fused bodies; giants; and one-legged humans were all believed to be descendants of Ham, as were the headless and those with a mouth on the chest. ${ }^{27,60}$

Additionally, such headless creatures, or even those with distorted head-neck formations, were denied status as men because they were believed to lack one of the four obligatory organs inherent to all humans (i.e., a fully human head-brain structure). Alexander of Hales (11851245) claimed that the lack of a normal human brain was made up for by other organs that took on the brain's function (i.e., the other organs made up for the lack of a seat of the soul). ${ }^{2}$ These early opinions of and concepts toward humans with abnormal appearances had great implications in creating the perceptions that would come to be adopted by later Europeans toward congenital malformations. 


\section{The Word "Monster"}

The Oxford English Dictionary (2016, www.oed.com) defines the word "monster" as "any imaginary creature that is large, ugly, and frightening." In today's society, it would be challenging to find someone who did not associate the word "monster," as applied to humans, with the concept of something horrible or aggressive, with fallen souls, or with dark evil spirits. Popular media and cultural examples, such as Boris Karloff's Frankenstein, Bela Lugosi's Count Dracula, Lon Chaney's Phantom of the Opera, and Lon Chaney, Jr.'s werewolf "The Wolf Man," conjure up such notions. Regardless of what makes these monsters unique, the fact that they are different from normal humans is justification enough to deem them ugly and frightening. In many ways, at least for European cultures from ancient times until the early 20th century, persons with congenital malformations or deformities were also deemed "monsters." However, centuries and generations ago the word "monster" did not have the same connotation that it has today.

The English word "monster" ("malformed animal or human, creature afflicted with a birth defect" [www. etymonline.com]) can be traced to the 12th century Old French "monstre" or "mostre" (monster, monstrosity), and directly from the Latin "monstrum," with meanings of divine omen, portent, sign, abnormal shape, monster, and monstrosity. Figuratively, the word described a repulsive character, an object of dread, an awful deed, or an abomination, and it was related to the Latin root of "monere" (to warn). Abnormal or prodigious animals were regarded as signs or omens of impending evil. By the late 14th century, the word was used in association with imaginary animals composed of parts of creatures (e.g., centaur, griffin). The meaning that associated a monster to an animal of vast size is from the 1520s; the sense of a person of inhuman cruelty or wickedness originates from the 1550s. The adjectival use of "monster" to mean something of extraordinary size became common in the 1830s. In Old English (Anglo-Saxon), the monster Grendel (from the epic poem Beowulf [CE 700-1000]) was an aglæca, a word related to aglæc, meaning calamity, terror, distress, or oppression, and it has a relationship to the Arabic 'alāg, meaning a miserable being, wretch, miscreant, monster, or fierce combatant. A common theme that characterizes all monsters by the current definition is their perceived deviation from the human race. The words "monster" and "monstrous" were used even until the early modern period in Europe in the context of signifying an abnormal birth or congenital deformity. Phrases from 16th century English texts, such as "a monstrous deformed infant," suggest that the term was used in a way to express deviation from the natural order, a separation from God, or even a being with outward human appearance but without a soul.

In the 17th century, the word "monster" became a technical term within medicine to signify a congenital malformation. This terminology remained commonplace even during the early 20th century, as noted in Feil's thesis and other contemporary medical publications. French physician François Bouchard, in a description of a patient in 1672, defined a monster as "anything that appears outside the usual course and order of nature such as a child with two heads or which has three or more arms or other superfluous members, mutilated or maimed."'11 The general population of early modern Europe viewed the word "monster" with great fascination and interest, as medical professionals were challenged to explain anatomically or physiologically what appeared to be unexplainable, or at least very mysterious.

\section{The Perception of Monsters in Early Europe}

During the 16th and 17th centuries in Europe, unprecedented interest in monstrous births ${ }^{72}$ paralleled a revived interest in the mysteries of anatomy and the morose. Publications on anatomy and dissection by prominent physicians and natural philosophers became widely read and discussed. However, the topic of monstrous births was not limited to scholarly publications but was also incorporated into popular prints, such as ballads, chapbooks, and advertisements. Books regarding the topic of monstrous births fell into two groups: "wonder" books, which presented monsters from a natural philosophical point of view in a similar fashion as other popular literature media, and medical books, which intended to analyze and explain monstrous births from a scientific perspective. The different perspectives presented by these two groups played an important role in molding society's perceptions of such human developmental abnormalities.

"Wonder" books originated for the most part with Protestants of various denominations and, as a result, each book represented the outlook and relationship with God of that particular religious doctrine. Authors of wonder books tended to focus on the analysis of isolated cases of congenital abnormalities, which they would proclaim as signs of God or the devil. These books emphasized morality and divine intervention as the primary culprit responsible for the congenital abnormalities. Pierre Boaistuau (1517-1566), the author of the 1560 Protestant wonder book Histoires Prodigieuses, ${ }^{10,56}$ believed that the purpose of monstrous births was to send a moralizing message to sinners:

It is most certain, that these monstrous creatures, for the most part do proceed of the judgment, justice, chastisement and curse of God, which suffreth that the fathers and mothers bring forth these abominations, as a horror of their $\sin .^{26}$

Despite the harshness of these words, Boaistuau believed that persons with abnormalities should be treated with Christian compassion because they represented a sign of God's divine power. Generally, wonder books described those with congenital malformations as messengers who brought "into the world no other news, but an admiration of the divine works of God." 70 Popular literature would play an integral role in establishing the perception that congenital malformations were a manifestation of sinful behavior, a perception that would take years of scientific investigation, demonstration, and reformation of stubborn biological theory to refute.

One of the earliest books to discuss medical points of view about monstrous births is Des Monstres et Prodiges (On Monsters and Marvels, 1573) by the French surgeon Ambroise Paré (1510-1590) (Fig. 3). ${ }^{48,55}$ Ambroise Paré was a pioneer in the field of surgery and was considered 


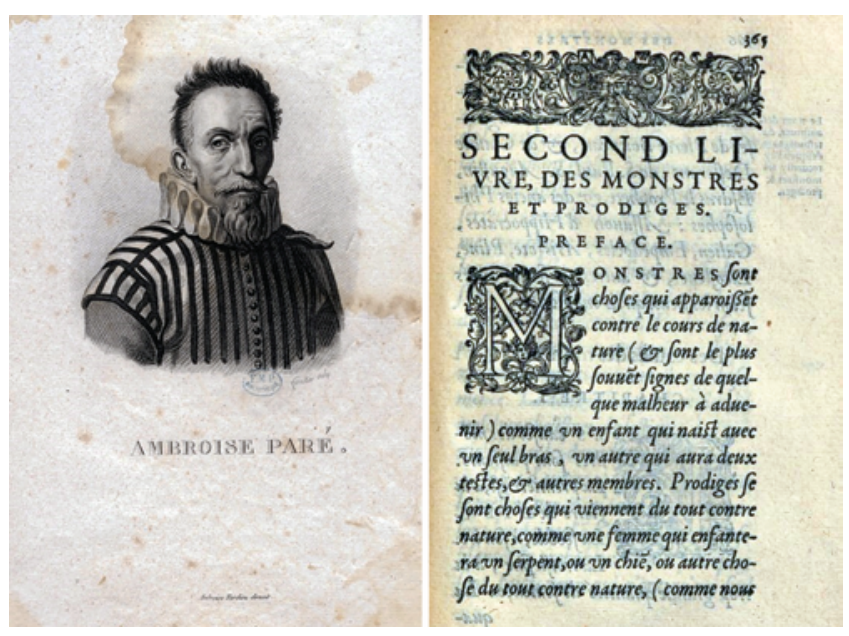

FIG. 3. Left: Engraved portrait of Ambroise Paré (1510-1590). From the portrait collection of the Bibliothèque interuniversitaire de Santé, Paris, France. Right: First page of the preface of the second book of Paré's "Two books of surgery" published in 1573. This volume is titled The Both Land and Sea Monsters With Their Portraits. These two books were aimed to raise surgery to the level of medical science, which met criticism from the medical faculty. In his second book, Pare attempted to combine all the known anomalies: congenital malformations, imaginary creature monsters, human-animal mix monsters, and real creatures. He viewed the abnormalities from the surgical standpoint of an era of religious conflicts and medieval outlook. A substantial part of his work is composed of congenital anomalies, in which he was interested as a surgeon. He was interested in the causes of the monster formation.

one of the best-known surgeons in France when he published Des Monstres. The book is among the first to suggest a classification for monstrous births and to propose causes rooted in anatomy and physiology. The first chapter of Des Monstres, titled "On The Causes of Monsters," provides a list of causes by which each monstrous birth can be classified:

The first is the glory of God.

The second, his wrath.

The third, too great a quantity of seed.

The fourth, too little a quantity.

The fifth, the imagination.

The sixth, the narrowness or smallness of the womb.

The seventh, the indecent posture of the mother, as when, being pregnant, she has sat too long with her legs crossed, or pressed against her womb.

The eighth, through a fall, or blows struck against the womb of the mother, being with child.

The ninth, through hereditary or accidental illness.

The tenth, through rotten or corrupt seed.

The eleventh, through mixture or mingling of seed.

The twelfth, through the artifice of wicked spital beggars.

The thirteenth, through the Demons and Devils. ${ }^{55}$

Paré, in his analysis, suggested that the hand of God also played a role in physical or physiological causes. He stated, "most often monstrous and marvelous crea- tures proceed from the judgment of God, who permits fathers and mothers to produce such abominations from the disorder they make in copulation." ${ }^{55}$ Despite assigning supernatural theories for each cause, Paré is viewed as among the first physicians to look at monsters as a matter of scientific inquiry and was considered a key figure in creating a new framework for studying abnormal births. Decades after Parés book, other attempts to shed light on monstrous births were published. Caspard Bauhin (1560 1624), a Swiss physician and botanist who also worked on anatomical nomenclature, published a classification of monstrous births in his 1600 book, De Hermaphroditorum Monstrosorum. ${ }^{6}$ His classification was based on contemporary theories concerning possible causes and was organized into a hierarchical tree.

In 1616, Fortunio Liceti (1577-1657), an Italian physician, classified monsters first by morphology and then into subgroups based on cause in his book, De Monstrorum Natura, Causis, et Differentiis (Fig. 4 ). ${ }^{46}$ Liceti was a strong supporter of the notion that monstrous births were due to natural causes and rejected the idea that they were a product of sinful behavior. Liceti's strong disapproval for the earlier theories of birth abnormalities is evident in the following passage from a 1905 book on monsters, in which the author provides translations from De Monstrorum:

"Monsters are produced merely when nature makes a mistake, and sin cannot result in the appearance of a monster", "[a] monster does not foretell the future", ... and "a monster does not signify evil"... "It is unbelievable", he [Liceti] wrote, "that God produces monsters in order to warn men of imminent catastrophes. It is not what they presage, but their rarity that makes the world wonder at them." ${ }^{5}$

During this same 16th- to 17th-century period, the topic of abnormal human anatomy and morphology not only was used by scientists, philosophers, and religious activists, but also was drawn upon by contemporary famous English writers. For example, William Shakespeare (1564 baptized-1616) mentions people born without heads in The Tempest: ${ }^{64}$

Faith, sir, you need not fear. When we were boys,

Who would believe that there were mountaineers

Dew-lapp'd like bulls, whose throats had hanging at 'em

Wallets of flesh? or that there were such men

Whose heads stood in their breasts? which now we find

Each putter-out of five for one will bring us

Good warrant of. ${ }^{64}$

Moreover, Shakespeare's Othello explains to the duke and the senate that he is an exotic traveler and has encountered adventures with primitive beings, probably such as the Blemmyes:

It was my hint to speak - such was the process:

And of the Cannibals that each other eat,

The Anthropophagi, and men whose heads

Do grow beneath their shoulders. These things to hear

Would Desdemona seriously incline. ${ }^{63}$ 

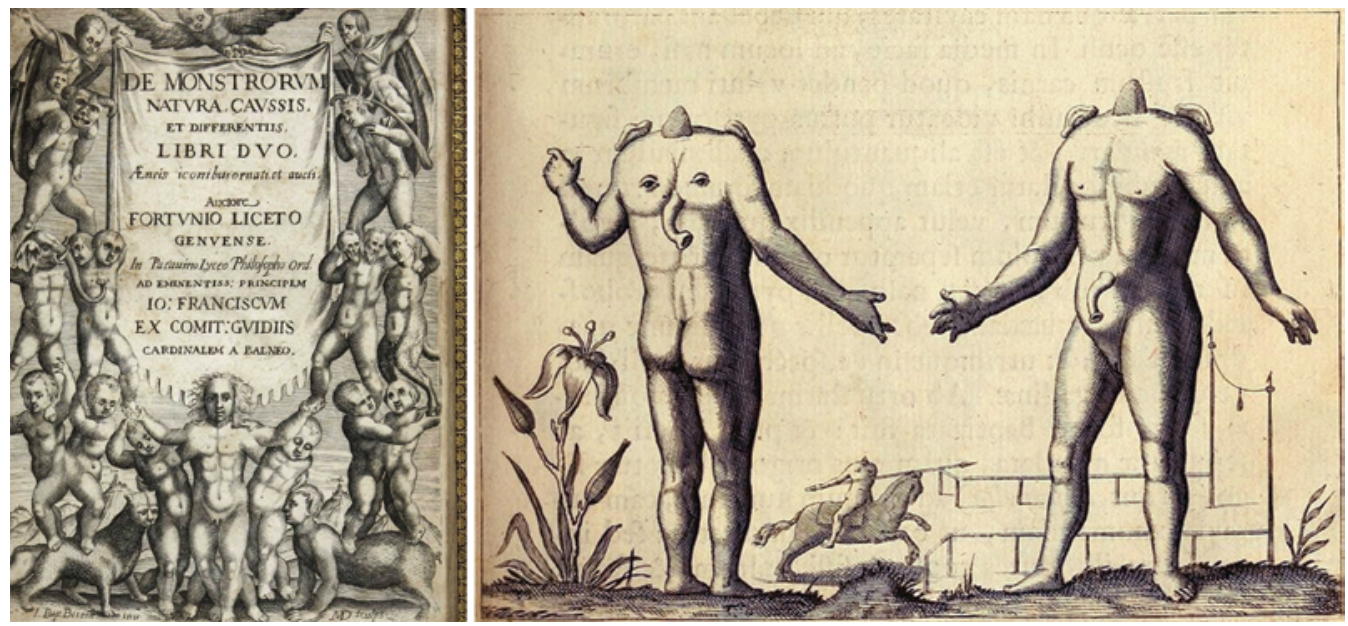

FIG. 4. Left: Illustration of the title page of the book by Fortunio Liceti (1577-1657), De Monstrorum Natura, Caussis, et Differentiis, Libri Duo (1634 first illustrated edition published in Padua). Right: Figure in the book showing headless creatures with eyes on their backs. This was an important tract published during a period of increasing interest in monsters throughout Europe, but by putting congenital malformations together with demonic and legendary or imaginary creatures, the author equated the two in the minds of readers.

French popular literature of the early 19th century continued to explore the conundrum of defining what is required for one to be classified as fully human. Although Victor Hugo's (1802-1885) novel The Hunchback of Notre Dame (originally titled Notre-Dame de Paris, published 1831) is set in the late Middle Ages during the reign of Louis XI (1461-1483), its main character, Quasimodo, represented this often-overlooked theme. Besides its thematic concentration on the value of significant architecture as a symbol for maintaining knowledge of, and connection with, the important aspects of human history, the work underscores through Quasimodo the social attitude toward individuals with malformations or deformities that still dominated Europe in the early 19th century. In fact, Hugo may have based Quasimodo on a hunchback who was a foreman of a government sculpting studio in Paris in the 1820 s and who worked on post-French Revolution restorations to Notre Dame Cathedral. ${ }^{54}$ Quasimodo is ascribed by the crowds to be the devil because of his horrible and repulsive outward appearance; however, in actuality he is filled with love and kindness. In fact, he was exchanged as a newborn because of his less-than-human hideous appearance-the baby Quasimodo was left by gypsies in place of Esmeralda, whom they preferred and abducted (Fig. 5).

Similarly, Mary Shelley's Frankenstein; or, The Modern Prometheus, published anonymously in 1818, then under her own name in 1823, explored similar ideas of humanness within a Gothic framework. In the novel, the monster does not have a name, as a human should, but is identified by words such as "creature," "monster," "demon," and "it." Speaking to Victor Frankenstein, the monster refers to himself as "the Adam of your labours," and elsewhere as someone who "would have" been "your Adam," but is instead "your fallen angel." The story is about the quest to become human. The beautiful creation of Frankenstein's dreams turns out to be hideous-a monster, with yellow eyes and skin that barely conceals the muscle tissue and blood vessels underneath. ${ }^{65}$ Revolted and disgusted with his work, Victor flees Geneva, while the rejected creature vanishes. Intelligent and articulate, the monster searches in vain to acquire humanness, but instead creates panic and fear. He has what man has given him, but he does not have what God could and must give him-a soul.

\section{Étienne Geoffroy Saint-Hilaire}

With the works of Liceti and others, the way that monstrous births and deformities were viewed began to change from a religious outlook to a more scientific one. Reinforcing this wave of change was the French scientist and natural philosopher Étienne Geoffroy Saint-Hilaire (1772-1844), whom Feil would reference multiple times in his own thesis. Geoffroy (Fig. 6) was a prominent French naturalist in the early 19th century who made great contributions to the fields of comparative anatomy and embryology and who is noted as a "creator of philosophical anatomy and teratology." 22 In 1822, he published one of his best-known works, Philosophie Anatomique, Monstruosités Humaines, a compilation of all his anatomical and teratological studies, observations, and theories. ${ }^{28}$ Feil, in his own thesis, recognized the importance of this book in changing the way monstrous births were studied and viewed, as he stated:

Étienne Geoffroy Saint-Hilaire, in his admirable book

"Anatomical Philosophy" had considered and discussed the importance of moral or physical causes that can disturb the pregnancy and determine monstrosities; he denied the influence of moral causes, emotion, etc. which popular belief has always attached great importance. ${ }^{22}$ [Translated from the French by I.S., E.B., and M.C.P.]

In the 1820s Geoffroy performed embryological experiments on chicken eggs to determine what external conditions could interfere with embryological development. ${ }^{4}$ During these experiments, he subjected the eggs to physical trauma and recorded any abnormalities that resulted from 


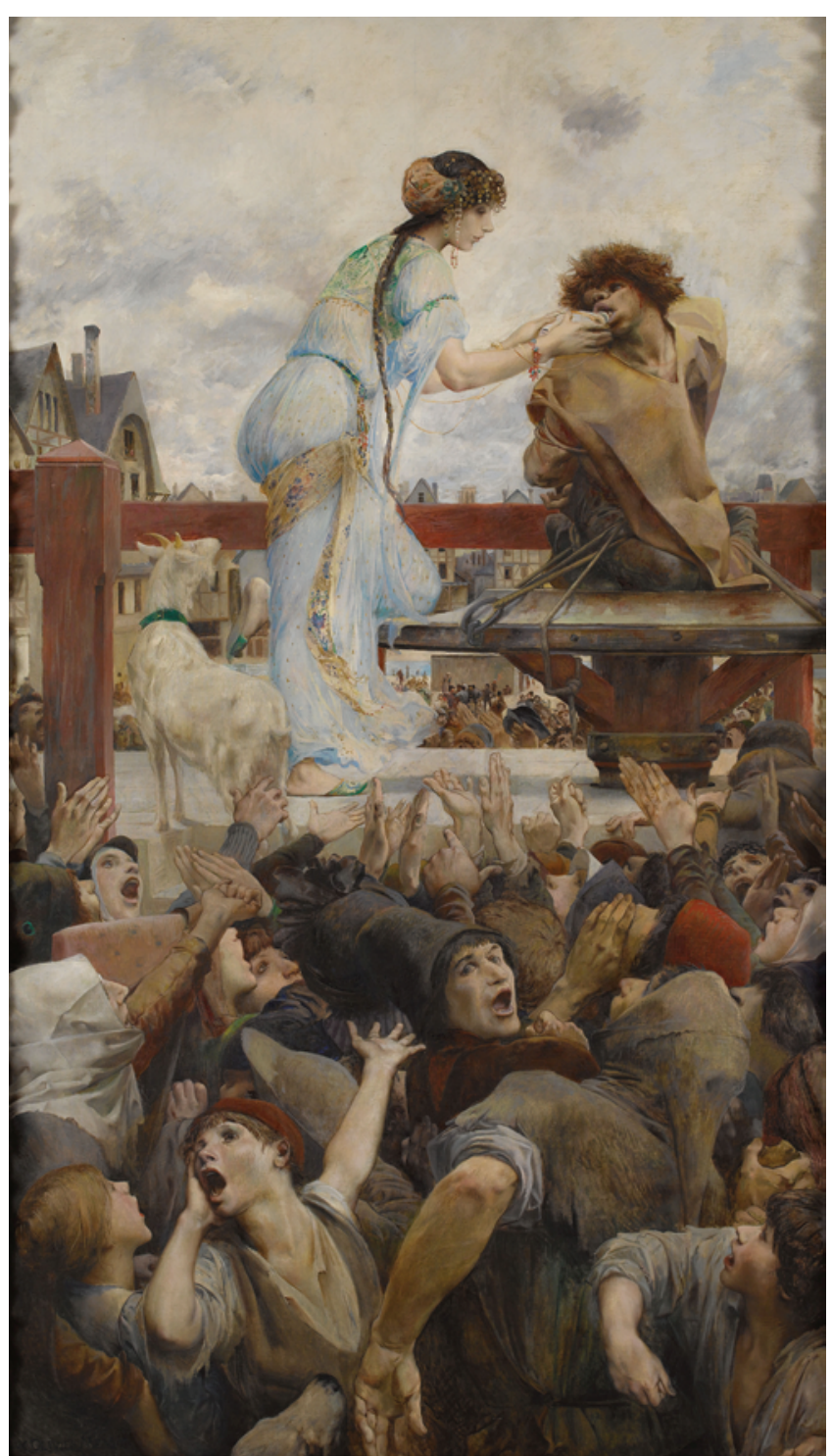

FIG. 5. Painting by Luc-Olivier Merson (1846-1920): "Une larme pour une gotte d'eau" (A tear for a drop of water), oil on canvas, 1903. Esmeralda offers water to Quasimodo, to the amazement, laughter, and revulsion of the crowd, as he faces ridicule and torture. This image is from the open public domain source Wikiart (http://www.wikiart.org/en/ luc-olivier-merson/esmeralda-and-quasimodo-1905).

the manipulation. Although he failed to maintain the fish stage or to obtain the transition to the mammalian stage of embryos, ${ }^{12}$ these experiments were fundamental in the creation of a new scientific field, experimental embryology and scientific teratology, the study of abnormalities in development. Geoffroy's work laid the foundation for future physician scientists like Maurice Klippel and André Feil to continue studying and refuting past theories concerning monstrous births. In fact, a monstrosity would come to define the medical legacy of Feil and his teacher, Klippel.

\section{André Feil and Maurice Klippel}

It is difficult to find information regarding the personal life of Feil. He was born in 1884 in Paris, France, and un-
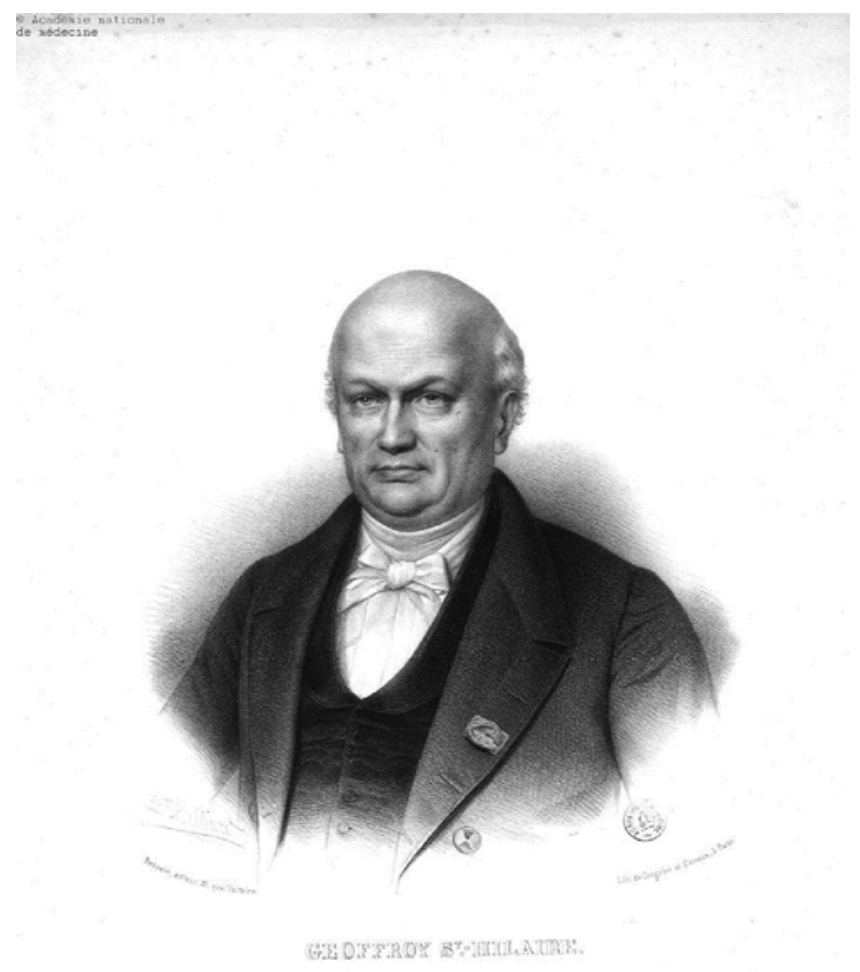

FIG. 6. A portrait of Étienne Geoffroy Saint-Hilaire (1772-1844). This prominent French naturalist and deist claimed a theory of unity in animal organism design according to which species could regress or progress during development, leading to transmutation over time. Together with Jean-Baptiste Lamark (1744-1829), he was at the forefront of the development and refinement of the theory of evolution in biology. Image copyright (c) Bibliothèque de l'Académie nationale de médecine (Paris), used with permission.

confirmed information indicates that he died in 1955 . He first studied in Tours, a university city located in central France, completing an externship (1907-1908) in the surgical clinic under Professor Pierre Delbert (1861-1957), who was a military surgeon. ${ }^{16}$ The following year of his rotation, he studied under Professor Henri Georges Eugene Roger (1860-1946), dean of the medical faculty, in the department of experimental pathology and comparative physiology. ${ }^{16}$ Roger was also Feil's doctoral thesis advisor, which may explain why Feil's thesis contains such comprehensive pathological descriptions and discussions on the possible mechanisms of abnormal development. From 1909 to 1910, Feil continued his externship under Professeurs Agrégés (i.e., Associate Professors) Sicard (given name unknown) and Mauritius Loeper (1875-1961), who was a pathologist. ${ }^{16}$

After completing his externship, Feil spent 3 years as a medical intern. His 1st-year mentor was Professor Paul Riche (1849-1933), who was a specialist in nervous diseases, hysteria, and hypnotism. ${ }^{16}$ From 1912 to 1913, Feil worked at the Hôpital Hérold in the center of Paris (Fig. 7). It was at this time that Feil began to work closely with Klippel (1858-1942) ${ }^{57}$ (Fig. 8), who seems to have singularly inspired and encouraged him.

Klippel was born in 1858 in Mulhouse, France, into a well-to-do family. He received his medical doctorate in 


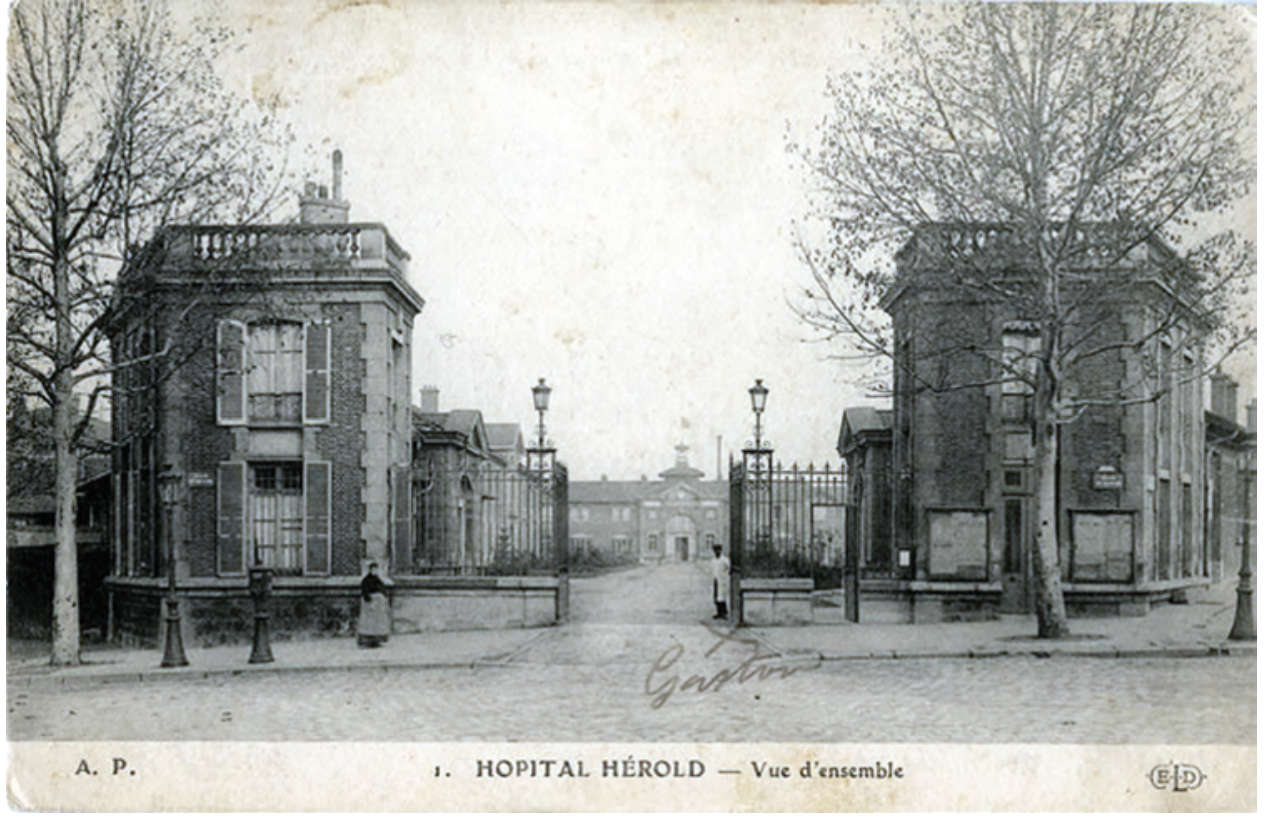

FIG. 7. Photograph of the facade and gates of the Hôpital Hérold (founded 1892, closed 1988), where Feil was a resident during 1911-1913. Nowadays, the grounds of the old Hôpital Hérold, between Sérurier Boulevard and Rhine-Danube in Paris, are preserved as a park.

1889; he served as a medical resident at the Hospitaux de Paris in 1884 and was a medical resident in 1886 at the Salpêtrière on the team when Joseph Babinski was the chief resident. Undoubtedly, therefore, Klippel had contact with Jean-Martin Charcot, although he is not listed specifically as one of Charcot's direct neurological descendants. Klippel became a member of the attending staff 5 years later and was chief of the service at the Hospice Debrousse for 1 year. In 1902, he became director of the department of general medicine at the Hôpital Tenon, where he remained until his retirement in 1924. He published articles on a wide array of medical topics, with his best-known written works being in the fields of neurology and psychiatry, but he also wrote on nonscientific topics. He died in 1942 in Vevey, France.

Much in the method of Charcot, Klippel was interested in neurology and psychiatry. He was described as an unparalleled clinician who insisted on a clinical impression and an exacting history and medical examination, believing that "illnesses concern the organism in its entirety, and that the pathologic changes did not confine themselves to one organ. ${ }^{.57} \mathrm{He}$ taught his students to become masters of, and to care for, the whole patient. There is little written about the relationship of student Feil to mentor Klippel, although a Klippel biography in the monthly Parisian medical humorous magazine ${ }^{1}$ (Fig. 9) written by "A.F." shares poignant knowledge:

If, by chance, passing by the heights of the Père-La-Chaise, you were to cross the Gambetta square around $10 \mathrm{am}$, you will see a little man come out of the subway station and take the direction of Hospital Tenon. You will observe, in every one of his movements, as well as his general appearance, the discreet
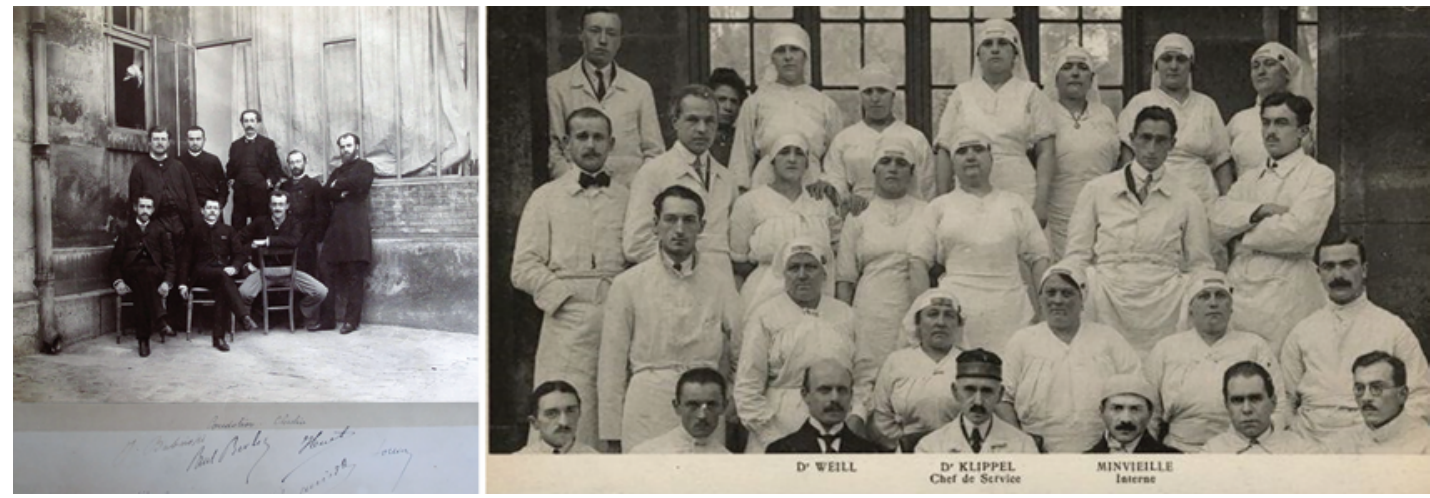

FIG. 8. Left: Photo from the album of internal medicine intern graduates in 1886 at the Salpêtrière, France. François Maurice Klippel is seated in the first row on the left, and Joseph Babinski, then chief resident, is standing directly behind him. Signatures are below. Right: This photo shows Klippel in 1922, as a chief of the general medical services at the Hôpital Tenon, France, 2 years before retirement. 

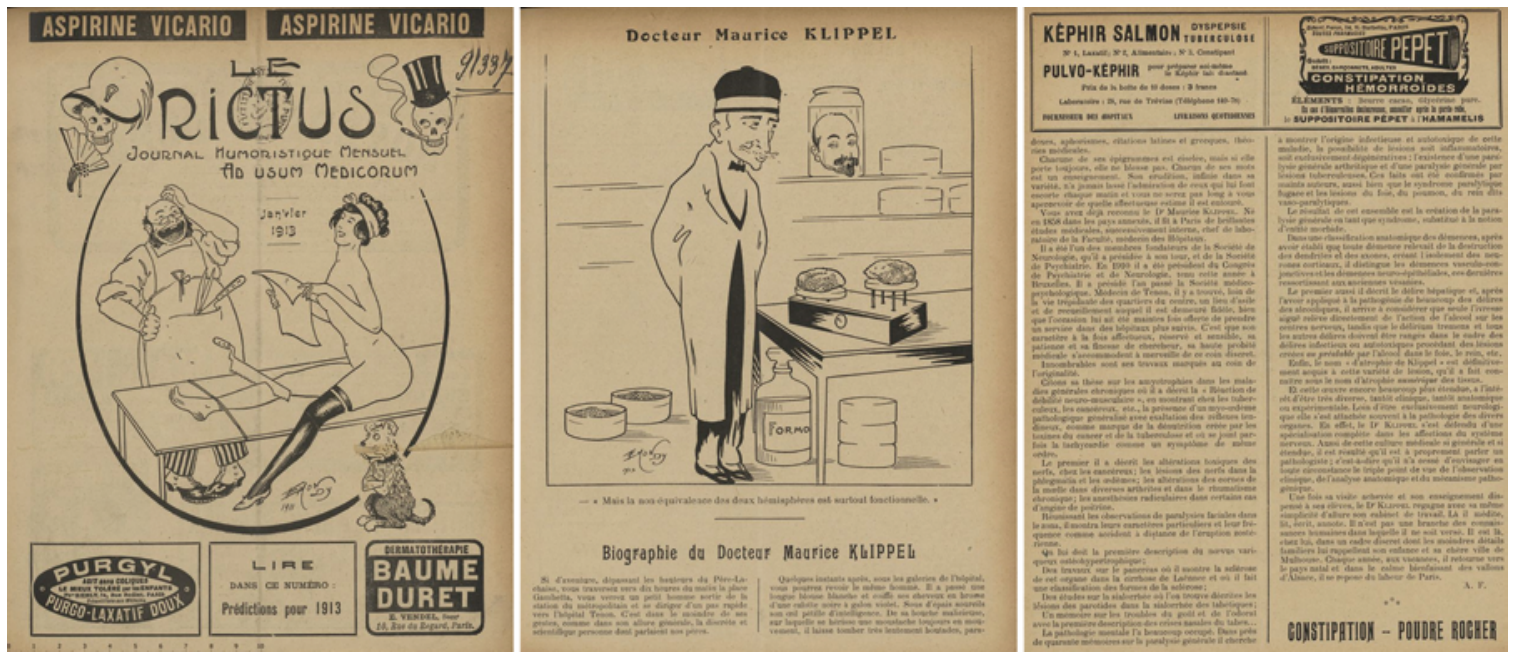

FIG. 9. Pages from the January 1913 issue of the humor journal Le Rictus, with a biography of Dr. Maurice Klippel written by A.F. (obviously by André Feil). This brief article in a comic magazine is one of only a few, and it attests to Feil's personality. The expression of his good sense of humor is a testimony to the relationship between interns and professors of the era. In this text, Feil described Klippel as a vivid, highly intelligent, yet incredibly discreet individual. The humoristic cartoon illustrates two hemispheres, representative of Klippel's famous work on the functional inequality of the cerebral hemispheres.

and scientific person our elders used to talk about. Moments later, under the hospital's covered passages, you will be able to see the same man. He will be wearing a long, white lab coat and will have covered his spiky hair with a black skullcap decorated with a purple stripe. Under his thin eyebrows, you will find vividly intelligent eyes. Out of his mischievous mouth, over which sits a continuously moving mustache, slowly come jokes, absurdities, aphorisms, Greek and Latin citations, as well as medical theories.

Every one of his epigrams is specific and meaningful, yet never hurts. Every one of his words is meaningful teaching. His scholarship, of infinite variety, has always obtained the admiration of those who have accompanied him every morning. You won't take long to understand that he is surrounded with loving respect.

You already recognized Doctor Maurice Klippel. Born in 1858 in the annexed country, he pursued brilliant medical studies in Paris, followed by his residency, then a position of chief of the Medical School Laboratory and ultimately physician of the hospitals.

He was a founding member of the Neurology Society, which he served as president of, as well as the Psychiatry Society. In 1910, he served as president of the Congress of Psychiatry and Neurology held in Brussels. Last year, he served as president of the medico-psychological Society. He remained a faithful Tenon physician, where he was able to find a place of refuge and sanctuary far from the hectic life in the center, despite multiple offers from more prominent hospitals. His affectionate, reserved, and sensitive personality, his researcher finesse and patience, as well as his high medical integrity, blend perfectly with this discreet environment.

His countless works bear the stamp of originality.

Let's start with his thesis on amyotrophies in general, chronic diseases in which he describes "the reaction of neuro-muscular infirmity" by describing the presence of a pathological generalized muscular edema with hyper-reflexibility as a sign of malnutrition caused by toxins in tuberculous and cancerous patients, etc.... Tachycardia can sometimes be associated with these symptoms.
He was the first to describe the toxic neurologic alterations found in cancerous patients, the nervous lesions in phlegmatia and edema, the alterations of the spinal cord horns found with different forms of arthritis and chronic rheumatism, as well as the radiculopathies found with certain types of angina.

By gathering the symptoms of facial paralysis found with shingles, he demonstrated the associations with herpes zoster eruptions.

We owe him the first description of the osteohypertrophic varicose nevus. He developed a classification of the forms of pancreatic sclerosis after demonstrating its presence in cases of Laennec's cirrhosis.

He studied syphilitic sialorrhea found in cases of parotid lesions. He wrote a memoir on his first description of the disorders of taste and smell found in patients with syphilis.

Mental pathology kept him quite busy. In nearly 40 memoirs on generalized paralysis, he attempts to demonstrate the infectious and auto-toxic origin of this disease. He discusses the possibility of inflammatory lesions as opposed to exclusively degenerative lesions: the existence of an arthritic generalized paralysis as opposed to a tuberculous paralysis. Multiple authors have confirmed these facts, whether a transient paralysis or lesions on the liver, lungs, or kidney said to be vasoparalytic.

This resulted in the creation of the syndrome of generalized paralysis, substituted for the notion of morbid entity.

He created an anatomical classification of dementia after establishing that all dementia resulted from the destruction of dendrites and axons, causing the isolation of cortical neurons. He distinguished vasculo-conjuctival dementia from neuroepithelial dementia, the latter representing the old disordered mental states.

$\mathrm{He}$ is also the first to describe hepatic delirium and to have associated it with the pathogenesis of many alcoholic deliriums. He was able to consider that only acute intoxication is a direct effect of alcohol on the central nervous system. Delirium tremens and all other types of delirium have to be classified under infectious or auto-toxic deliriums, arising from existing lesions caused by alcohol in the liver, kidney, etc.... 
Finally, the name "Klippel atrophy" is associated with the lesions he well described under the name of numeric atrophy of the tissues.

His work, even more extensive than described, is very diverse, ranging from clinical to anatomical or experimental. Far from being solely directed to neurology, his work was often directed to the pathology of various organs. Dr. Klippel refused to specialize only in diseases of the central nervous system. From his generalized and vast study of medicine, one can properly call him a pathologist. He never stopped to include the trifecta of clinical observation, anatomical analysis, and pathological mechanism.

Once he has finished his rounds and taught his medical students, Dr. Klippel returns to his office with his usual simplicity. There, he meditates, reads, writes, and annotates. He does not belong to a type of humanity where continuous knowledge is not poured in. He is there, at home, in a discreet environment, reminding him of the familiar details of his beloved childhood city of Mulhouse. Every year, during his vacation, he returns to his birth country, the calming hills of Alsace, where he relaxes away from the Parisian work. ${ }^{1}$ [Translated from the French by I.S.]

Amid the dispute and cloud of uncertainty regarding the origins of monstrous births, Feil entered the academic discussion with a publication describing a congenital abnormality, now named after him as well as his mentor, Klippel. The initial report entitled "Un cas d'absence des vertébres cervicales cage thoracique remontant jusqu'a la base du crâne" (A case of absence of cervical vertebrae with the thoracic cage rising to the base of the cranium) was published in 1912 after Klippel, then the attending neurologist at the Hôpital Tenon (Fig. 10), and his resident Feil, came in contact with a patient with an "exceptional formation." $40,41,43,57$ Klippel and Feil also presented the case to the Société d'Anthropologie de Paris on March 21, $1912 .{ }^{43}$ Feil summarized the case history in his thesis, concentrating on the spinal abnormality.

The patient, a 46-year-old French tailor by the name of L. Joseph, presented on December 13, 1911, at the Hôpital Tenon with a unique triad of low hairline, limitation of movement of the neck and head, and multiple fused cervical vertebrae. He was admitted to the hospital for pleurisy and pulmonary congestion with nephritis, he had albumin in his urine, and he had "a large heart with rapid beats (bruit de gallop). He died January 19, 1912 [with massive uremia]. ${ }^{33}$ On the first physical examination, his appearance was striking-"the head resting on his trunk astonished us. ${ }^{33}$ In his thesis, Feil wrote:

He appeared to have no neck, the head seemed to rest on the trunk.... In our patient we could find nothing which could explain the situation.... We wish to stress the absence of all hereditary skeletal anomalies in this family. We questioned him, but his personal and family history has nothing to do with this anomaly. We emphasize that there was no skeletal deformity among his relatives. The patient knows nothing about his birth, but remembers only that at age 7 , he was brought to a physician who proposed an operation. At that time, he remarked, his head deviated to the left, and his ear touched his shoulder.... [s] ince the age of 10 years, he has had frequent long stays in the hospital for various problems: appendicitis, pleurisy, chronic bronchitis, and despite so many examinations, no one had ever assessed the strange deformity he presented..$^{22}$ [Translated from the French by I.S., E.B., and M.C.P.]

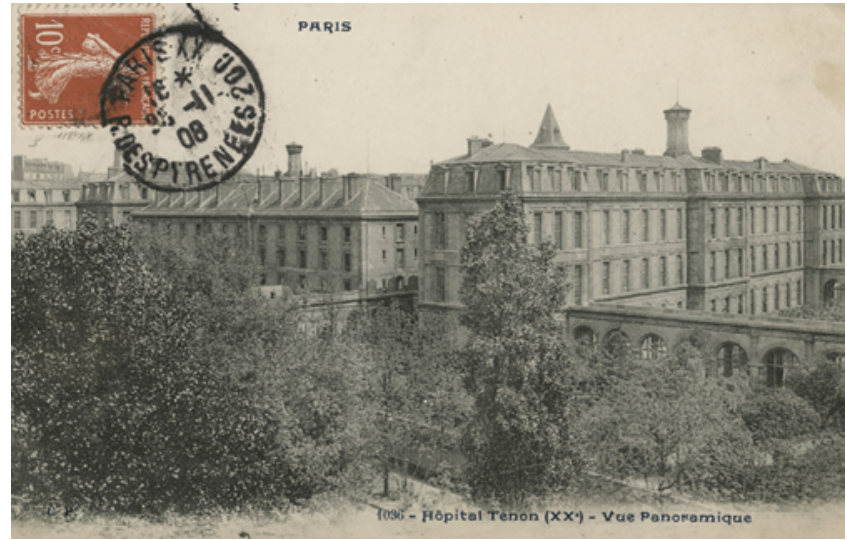

FIG. 10. Postcard dated 1908 showing a panoramic view of the Hôpital Tenon, Paris, where the patient in the first case described by Klippel and Feil was admitted. Photograph from the Bibliothèque de l'Académie nationale de médecine (Paris). The image is reproduced under the freeto-reuse license. Collection BIU Santé Médecine, Ref image CISA0951. Open source (http://www.biusante.parisdescartes.fr/histoire/images/ index.php?refphot=CISA0951).

Although Feil's thesis presented the first comprehensive description of this congenital abnormality, Feil used the thesis in a far greater role to contradict the popular notion at the time that a monstrous birth or congenital deformity could be explained on an atavistic or ontological basis. Within the report, Klippel and Feil stated:

The pathogenicity of these vertebral variations is complex and uncertain; many hypotheses have been developed and the number of theories is proof of the obscurity which surrounds them. So the case which we have reported is difficult to explain by any of these theories. We are not in the presence of variation regressive or progressive, but of a monstrosity. The etiology is uncertain, it is perhaps traumatic, it is also possibly the result of an infectious osteitis which upset the entire upper part of the vertebral skeleton. ${ }^{41}$ [Translated from the French by I.S., E.B., and M.C.P.]

Even in the early 1900 s, while attempts were still being made to connect monstrous or deformed births with a regression or moral failing, Klippel and Feil were among the first to openly refute that any such relationship resided and instead suggested other causes. Feil pursued the message conveyed through this report concerning the origins of monstrous births in his own thesis.

\section{André Feil's Thesis}

In 1919 Feil published his doctoral thesis, entitled L'Absence et la diminution des vertèbres cervicales (étude clinique et pathogénique) (The absence and the decrease of cervical vertebrae [clinical and pathogenetic study] $)^{22}$ (Fig. 11). Feil used the single case of L. Joseph observed with Klippel and supported it through a detailed pathological examination and data from the scientific literature to write his thesis, published 6 years after the initial paper by Klippel and Feil. The other two colleagues he worked with in the Hôpital Hérold were the dermatologist and mycologist Charles-Lucien de Beurmann (1851-1923) and Doctor Lesage (given name unknown), respectively. 


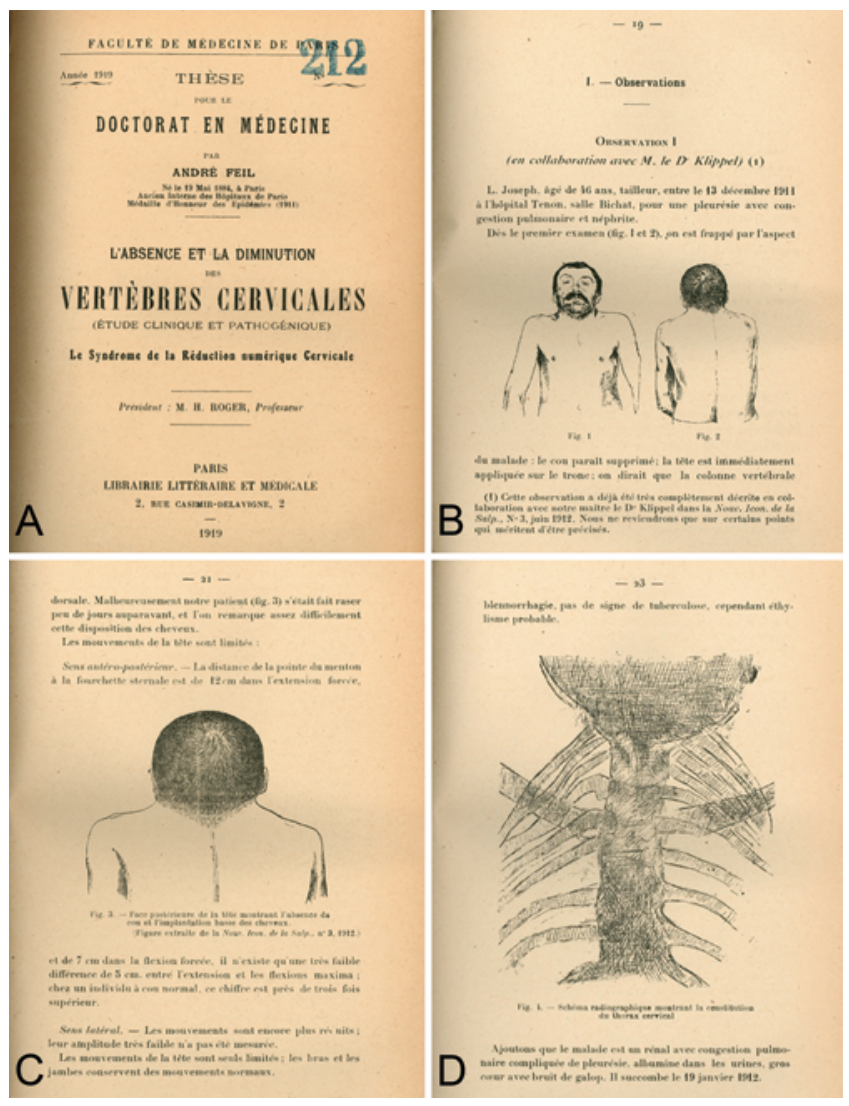

FIG. 11. A: The title page of André Feil's 1919 doctoral thesis. On the second page, he wrote: "To Mister Dr. Klippel: He was my watchful guiding light. I hope he gives me permission to dedicate this work to him as a tremendous gratitude. To my late advisor, professor Ledouble of Tours, to my hospital advisors." B and C: Illustrations showing L. Joseph, a 46-year-old French tailor admitted to the Hôpital Tenon with recurrent pleurisy, pulmonary congestion, and nephritis $\mathrm{D}$ : Diagram of radiographic findings of $L$. Joseph, from Feil's thesis.

The thesis presented a general overview of abnormalities, with remarks on the work of past researchers, such as Geoffroy, on the topic of congenital malformations. In this portion of the thesis, Feil expressed views on why congenital malformations have held such interest in the eyes of the public throughout the course of history:

This ignorance, this difficulty to explain the anomalies and monstrosities are perhaps their main attraction; their cause, their disposal, the differences and similarities with what we see in living things, all evoke countless reflections that affect the complex problem of the relationship between man and animals. ${ }^{22}$ [Translated from the French by I.S., E.B., and M.C.P.]

Despite this interest, Feil pointed out that little was done to truly understand the origins of monstrous births due to "the superstitious ideas that then dominated all minds...." 22 His ideas were bold but necessary for the time, and Feil used the opening of his thesis to shun any notion that monstrous births were the result of supernatural causes, as many in the general population still believed.

From this practical point of view, it seems most useful to consider malformations by describing their signs, by which we reach their diagnosis more easily and treat them better. It may well be, when clinical research will be more advanced, you will advantageously replace this [current archaic system] with pure clinical classification of anomalies, which divisions at the present time are based on the anatomy, embryology, or philosophy. It is in this spirit that we propose to study an undescribed and unacknowledged bone malformation of the cervical spine which seems to have a certain pathogenic and especially clinical interest. ${ }^{21}$ [Translated from the French by I.S., E.B., and M.C.P.]

The main portion of the thesis primarily analyzed cases of deformities or the absence of cervical vertebra. Feil used the case from his own practice with Klippel, as well as information about other cases sent to him by colleagues. He stated that there were not many examples of actual reduction in the number of cervical vertebrae, even adding cases of malformations seen in fetuses. He used the following previously published cases, which he found in Guérin's monograph. ${ }^{30}$ The first three cases he claimed were described by Haller ${ }^{30}$ in 1745 , Morgagni51,52 in 1746, and Béclard7 (cited by Feil from Guerin pp. 251, 251, and 418), ${ }^{30}$ and Goodhert in 1874. ${ }^{29,32}$ Additional cases were drawn from Willett and Walsham in $1880,{ }^{71}$ Varaglia from the University of Turin 1882 (no citation provided by Feil), Staderini in 1894 (no citation provided by Feil), Kabaud in 1907 (no citation provided by Feil), Nau in $1904,,^{53}$ and Bertolotti in 1917. ${ }^{8}$ The thesis is organized into chapters, the first being divided according to Feil's suggested method for classifying cervical abnormalities causing the numerical reduction of vertebrae, a method still used today.

Additionally, 6 of 12 cases $^{8,9,43,44,47,50,53,66,71}$ (Table 1) were given to Feil by the famous Italian surgeon and radiologist Professor Mario Bertolotti (Fig. 12), who was director of the Institute of Medical Radiology of the Maggiore Hospital, Turin, working from 1906 until 1953 $3^{16,32,69}$ and considered a founder of Italian neuroradiology. ${ }^{45}$ Bertolotti, who had studied with Charcot at the Salpêtrière, was also interested in congenital anomalies and was best known for his work concerning a syndrome in which there is articulation between the L-5 transverse processes and sacrum, which he described in a 1917 article, "Contributo alla conoscenza dei vizi differenzazione regionale del rachide con speciale riguardo all assimilazione sacrale della V. lombare" (Contribution to the knowledge of the vices of regional differentiation of the spine with special regard to the assimilation of the fifth lumbar vertebrae into the sacrum). ${ }^{8}$ His 1920 monograph, "Le anomalie congenite del rachide cervicale" (Congenital anomalies of the cervical spine), ${ }^{9}$ referencing Feil's thesis, distinguished three clinical types of cervical malformations: the first type is similar to Feil's classification, but the second and third types have different descriptions and are characterized by torticollis related to skeletal deformities (Type 2) or muscular torticollis with atlantooccipital fusion (Type 3) ${ }^{9,49}$

Moreover, Feil noted the combination of three signs present in the clinical syndrome of Type 1 anomaly, which would later become the clinical syndrome of Klippel-Feil: low hairline, absence of neck, and limitations in head movement. ${ }^{22} \mathrm{He}$ concluded that low hairline is associated with the bony anomaly, as were other causes of hypertrichosis suggested by Nau. ${ }^{53}$ Feil wrote that the prognosis for individuals with such deformity is precarious. Particularly important to Feil's thesis are the differential diagnoses associated with this syndrome, which should be dis- 
TABLE 1. Observations that composed the basis of the Feil's thesis

\begin{tabular}{|c|c|c|c|}
\hline $\begin{array}{c}\text { Type \& } \\
\text { Patient No. }\end{array}$ & Author/Case Provided to Feil & Year Published & Content in the Thesis \\
\hline \multicolumn{4}{|l|}{ Type I } \\
\hline 1 & Maurice Klippel \& André Feil & $1912^{43}$ & $\begin{array}{l}\text { Described physical findings, radiographic examination, extensive de- } \\
\text { scription \& image of autopsy findings, including description of thorax, } \\
\text { vertebral column, cervical-dorsal mass, thoracic vertebrae, lumbar } \\
\text { vertebrae, discussion of the case (ribs \& vertebrae) }\end{array}$ \\
\hline 2 & Ronald O. Meisenbach & $1913^{50}$ & Description of physical findings \& radiograph \\
\hline 3 & Mario Bertolotti & $\begin{array}{l}\text { Possibly published in } 1917 \\
\text { by Bertolotti }{ }^{8} \text { or in } 1920 \text { by } \\
\text { Mattirolo \& Bertolotti }{ }^{47}\end{array}$ & Correspondence of Bertolotti (description of physical appearance) \\
\hline 4 & $\begin{array}{l}\text { Mario Bertolotti \& G. Mattirolo } \\
\quad \text { from Turin }\end{array}$ & $\begin{array}{l}\text { Possibly published after } \\
\text { Feil's thesis by Bertolotti } \\
\text { in } 1920^{9}\end{array}$ & $\begin{array}{l}\text { Clinical examination, radiographic examination, correspondence w/ } \\
\text { Bertolotti on radiography findings }\end{array}$ \\
\hline 5 & Mario Bertolotti & Unknown & W/o full description, as documentation \& films were lost \\
\hline 6 & Le Lorier \& Robert Dupont & $1911^{44,66}$ & Description of a neonate (multiple anomalies) who died in 2 days \\
\hline \multicolumn{4}{|l|}{ Type II } \\
\hline 7 & Mario Bertolotti & Unknown & $\begin{array}{l}\text { Description of clinical \& radiographic findings in a 7-yr-old boy; ( } 6 \text { cervi- } \\
\text { cal vertebrae, w/ fusion of C-3 \& C-4) }\end{array}$ \\
\hline 8 & Mario Bertolotti & Unknown & $\begin{array}{l}\text { Description of clinical \& radiographic findings in an 18-yr-old man } \\
\text { (occipitalization of axis; atlas was rudimentary \& poorly differenti- } \\
\text { ated; absent C-3 was replaced by small bone fragment; C4-7 were } \\
\text { reduced in height \& fused, as reported [no radiographic image]) }\end{array}$ \\
\hline 9 & Mario Bertolotti & Unknown & $\begin{array}{l}\text { Father of patient in Case 8, description of clinical \& radiographic findings } \\
\text { of C-1 occipitalization \& C2-3 fusion }\end{array}$ \\
\hline \multicolumn{4}{|l|}{ Type III } \\
\hline 10 & Paul Bar & $\begin{array}{l}\text { Published in bulletin of the } \\
\text { Obstetrics Society of Paris } \\
\text { in Nov } 1903 \text { \& May } 1904\end{array}$ & $\begin{array}{l}\text { Description of case of neonate w/ radiograph (not presented) show- } \\
\text { ing irregular development of cervical spine, reduced height of the } \\
\text { vertebrae }\end{array}$ \\
\hline 11 & Paul Bar & Unknown & Description of sister of patient in Case 10, a 1-yr-old girl w/ short neck \\
\hline 12 & Pierre Nau & Thesis, $1904^{53}$ & \\
\hline 13 & Serres & Unknown & Skeleton of headless fetus from museum \\
\hline 14 & Alfred Willett \& W. J. Walsham & $1880^{71}$ & $\begin{array}{l}\text { Short mention of a } 31 \text {-yr-old woman w/ scoliosis \& } 2 \text { cervical, } 7 \text { thoracic, } \\
\text { \& } 3 \text { lumbar vertebrae }\end{array}$ \\
\hline
\end{tabular}

tinguished from torticollis and suboccipital Pott's disease, which was prevalent at the time. ${ }^{22}$

The thesis mentioned possible causes for cervical vertebrae absence or malformations. Feil did not discuss, but mentioned, the possibility of pathological causes such as "tuberculosis, alcoholism, syphilis, smallpox, heart disease [and] madness" playing a role in forming malformations in children born to parents with one of these illnesses. He also referenced that genetics, although not well understood at the time, may also contribute to congenital malformations, writing "the facts of heredity cannot be considered negligible, they must be taken into account for the study of the mechanism of production of any anomaly." 22

Feil mentioned other possible etiologies, including trauma to the fetus during development and elevated amniotic pressure, and while he used the term "monstrosity," he distanced the term from past connotations of blame. He refrained from providing legitimacy to past theories on origins suggesting that congenital anomalies were a form of human digression or a sign of moral failure. Instead, he proposed using modern technology to assess the clinical state of the patient: "Radiography, facilitating a discovery of life, indicates the relationship between the structure of the vertebrae and clinical signs, has completely transformed the study of anomalies of the spine and permanent deformities of the trunk that are a usual consequence." 22 The Conclusions section of his thesis is clear from the standpoints of rejecting unsupported theory and describing precisely the pathology and his scientific reasoning:

Conclusions:

1) The cervical region, just like the other areas of the vertebral column, can present with missing or extra numerical variations.

The variations by default, the only ones of interest to us, are almost always related to severe morphological anomalies which often present as real monstrosities. There are quite a few of these cases, much more than suspected, but they are often misdiagnosed as sub-occipital Pott's or torticollis.

2) A reduction of numbers can present anatomically or clini- 


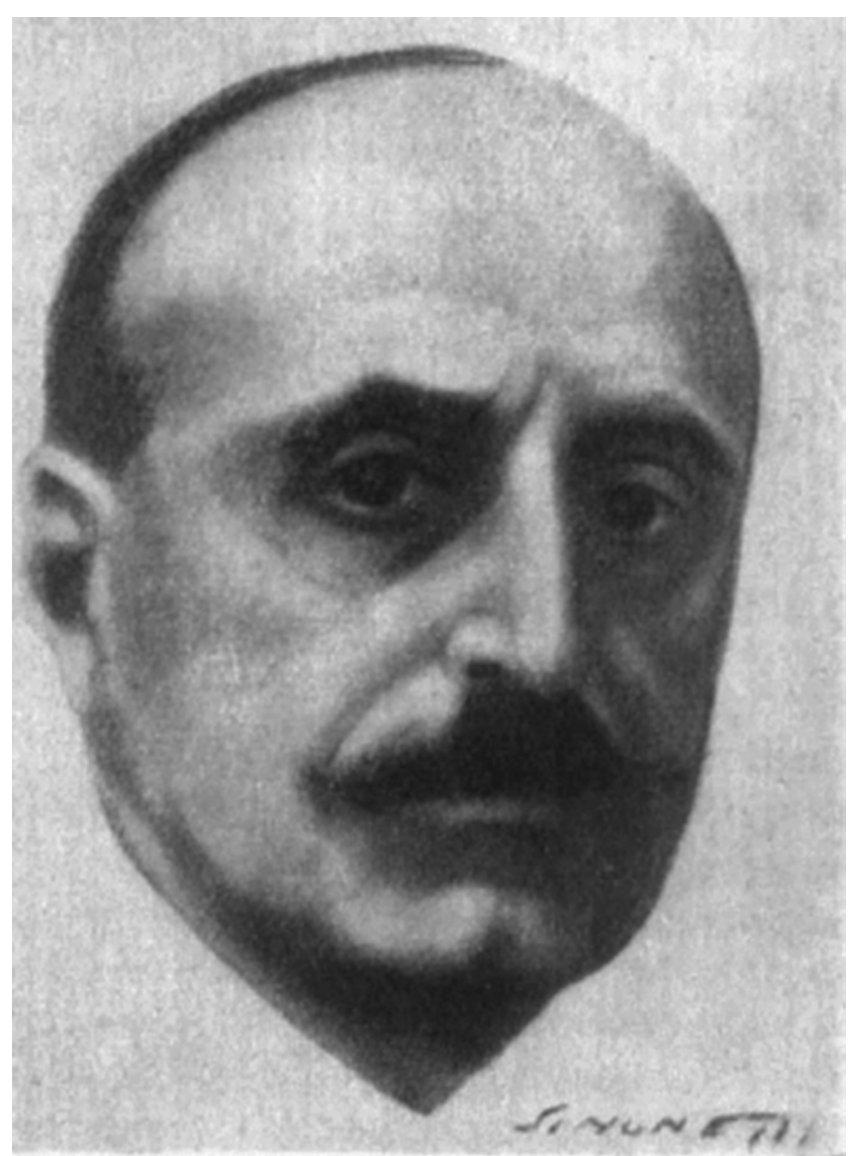

FIG. 12. Portrait of Mario Bertolotti (1876-1957), prominent Italian radiologist. From Ospedale Maggiore di S. Giovanni Battista e della città di Torino e cliniche universitarie (nuova sede). Gruppo stampa e Propaganda educativa, Torino 1929. http://digit.biblio.polito.it/id/ eprint/3458.

cally as a wide spectrum from the complete absence of the cervical column to the absence of only one vertebra.

We will distinguish 3 types:

Type I.-This is the type that can be isolated best. Lesions are only in the cervical column. The rest of the spinal column is completely normal.

The monstrosity can be identified by several anatomical and clinical markers:

Anatomically, you will always find:

A cervico-thoracic mass comprised of atrophied cervical vertebrae as well as the first 3 or 4 thoracic vertebrae.

An opening of the first vertebral arches.

A considerable elevation of the chest cavity, sometimes all the way to the base of the skull.

With this anatomical presentation, a true clinical syndrome can be observed:

Low-lying hairline

Absence of neck

Clear limitation of head movement

These 3 principal signs, compounded with other less important ones, should always raise suspicion of an underlying congenital malformation. If all symptoms are found together and clearly present, you need to work up the isolated absence of cervical vertebrae.

We believe this congenital abnormality to be relatively frequent; it is still unknown: some patients hold their head very straight without obvious deformities (several have spent a long time in various hospital departments without ever being identified), usually because these patients have been misdiagnosed as having sub-occipital Pott's disease. We will avoid the misdiagnosis by systematically searching for this absent cervical vertebrae clinical syndrome every time the diagnosis of Pott's disease, torticollis, or cervical region deformity is raised.

Clinical signs raise the possibility of congenital abnormalities and lead the clinician to order radiographs, which will give the diagnosis.

We believe the origin of this monstrosity is as such:

First, spina bifida occurs (represented by the posterior triangular orifice), spina bifida having to be located at the superior [cephalad is the word used today] end of the spinal column. Second, trauma or more likely amniotic compression generates progressive packing of the spinal bifida zones: cervical column and first thoracic vertebrae.

The abnormality probably occurred late, likely in the 3rd or beginning of the 4th month of gestation: during this period, the fragility of the cervical column determined by the nonclosure of the posterior arches (spina bifida) is increased by the absence of ossification of the bodies of the cervical vertebrae. This ossification is, by then, already very advanced in the remainder of the spinal column.

As a general rule, this monstrosity (Type I) makes up a clearly homogenous group clinically and anatomically, as well as from its pathogenesis standpoint.

Type II.-The reduction is limited to one or two cervical vertebrae. Along with this less involved anatomical abnormality, one will observe an attenuation of symptomatology. This group is comprised of complex morphological disorders such as fusion, hemivertebrae, occipitalisation of the atlas, etc.

Type III.-There is a compression in or a numeric reduction of cervical vertebrae, just like in the previous groups; however, the lesions are not confined to the cervical column. They can be found throughout the spine. This spread leads to a less clearly defined clinical syndrome.

These important congenital anomalies are hardly compatible with life. They are, therefore, typically seen in the fetus or neonate.

3) Pathogenesis-Generally speaking, the pathogenesis of these monstrosities of the spinal column is obscure.

Although Type I monstrosity seems to be of mechanical origin (amniotic pressure), most seem to want to associate it with a specific pathology.

This cause, whether mechanical or pathological, is rarely associated with an obvious event (accidental trauma, maternal or fetal illness during pregnancy). We generally never find an obvious source for the congenital abnormality. In certain suspicious cases, as described by Isidore Geoffroy SaintHilaire and other authors, we would gladly blame attempted abortions, whether conscious or not, as having influenced the fetus directly or indirectly by causing disorders in amniotic development.

4) After studying the pathogenesis of Type I monstrosities, three facts appear to be of utmost importance: 
a) Spina bifida can sometimes occur in the inferior or middle cervical regions; however, it can exceptionally occur at the very superior (cephalad) portion of the spine. We believe that this rarity is only fictive as, very often, spina bifida of the first vertebrae is accompanied by a compression, which appears like monstrosity Type I and is often misdiagnosed as Pott's disease. This is why this rarity of existence of superior (cephalad) spine spina bifida is fictive.

b) Spina bifida, independent of its location on the spine, creates a particular fragility of the spine immediately adjacent to the lesion, thereby explaining certain vertebral anomalies.

c) Congenital scoliosis, unlike what we tend to believe, is not always related to vertebral anomalies (fusion, hemivertebrae, sacralisation, etc). M. Rachaud's research has shown that it can develop without the presence of previous vertebral anomalies and that it can simply develop from a mechanical action of the spine on a pre-existing primitive abnormality of the medullary nervous axis.

In this work, we attempted to show that the study of anomalies and monstrosities is not only theoretical but also can present a clear clinical interest. It should be possible to develop analogous clinical syndromes to the syndrome of cervical numerical reduction for other congenital anomalies. ${ }^{22}$ [Translated from the French by I.S., E.B., and M.C.P.]

However, perhaps the most prescient and insightful portion of Feil's thesis immediately precedes the conclusion. This section presents his thoughts on deformities and the word "monstrosity," but also on the wisdom passed to him by Klippel:

We still know very little about variations-monstrosities; one generally ignores their morphological and clinical characteristics, as one hesitates about their origin. With the help of comparative anatomy, by studying specifically the clarity of development, trying to categorize them chronologically in the flow of time as the vivid expression of [Mathias] Duval and [P] Mulon [French pathologists performing embryological investigations], working a bit like a geologist, it appears that we could divide and better understand these still-unexplained variations-monstrosities, as we have tried here regarding the reduction of cervical vertebrae. The primary cause often escapes us. Do not despair, the science will succeed one day to discover the causes that generate the human monsters, like [Camille] Dareste that could induce simple monsters that occur in the class of birds [Camille Dareste's "production artificielle des montruosités"15 ].That's when we really come to a practical conclusion and knowledge, in these cases one could be expected to act on them and facilitate normal development of the embryo in the human species. The clinic provides less uncertainty about the pathogenesis. It seems possible to describe particular signs of certain monstrosities, sometimes, as in Type I malformation, a true clinical syndrome that attracts attention, facilitates diagnosis in the living man, and avoids errors that may have a therapeutic consequence. Proving that monstrosities are not always random products, they are not as irregular as it might seem, but obey certain rules; showing that it is possible to draw a clinical picture for each group of anomalies is the goal that we had proposed regarding the monstrosities that are related to the absence or reduction of the cervical vertebrae. ${ }^{22}$ [Translated from the French by I.S., E.B., and M.C.P.]

Feil's 1919 thesis not only became a medical gem, reporting additional cases, but it also provided a classification system largely still in use today. Moreover, it was a progressive medicosocial tract, reinforcing the idea that those with congenital malformations should not be looked upon as examples of regression in human development or evolution, or more simply, as less than fully human.

\section{Transition to a Modern View of Klippel-Feil Syndrome}

Cases involving Klippel-Feil syndrome have been found dating back to early human history. The discovery of the remnants of two individuals with Klippel-Feil anomaly during an archeological investigation of sacrificial Mayan burial assemblage in Midnight Terror Cave in Belize was recently reported. The author interpreted these findings as supporting the hypothesis that physically handicapped persons were used for sacrificial purposes in Mayan culture. $^{39}$ This example further highlights the implications that congenital malformations influenced sociocultural traditions, and it reveals how society viewed persons with severe malformations in different cultures and eras. However, persons with mild Klippel-Feil anomaly and without pronounced phenotypical changes have been found to be present in earlier ages. For example, one documented case involved an adult male (M9) with fused cervical vertebrae, whose skeletal remains were found in a late Neolithic site in Vietnam; he was assumed to have had juvenile-onset quadriplegia and appeared to have been supported in life. ${ }^{68}$

Currently, Klippel-Feil syndrome is observed as a syndrome that unites a heterogeneous group of patients only by the presence of a congenital synostosis of two or more cervical vertebrae. ${ }^{62,67,69}$ Attempts have been made to further subdivide this heterogeneous group of patients. For example, Samartzis and colleagues proposed a classification method based on radiological findings found in patients with Klippel-Feil syndrome. ${ }^{61}$ This classification also divides patients into three types, but differs from the one proposed by Feil. In the classification system proposed by Samartzis et al., Type 1 is characterized by the presence of a "single congenitally fused cervical segment"; Type 2, by the presence of "multiple noncontiguous, congenitally fused segments"; and Type 3, by the presence of "multiple contiguous, congenitally fused cervical segments." ${ }^{\prime \prime}$

It should be noted that there is more than one classification method that categorizes patients with Klippel-Feil syndrome; the author of the reference to the classification should be named to avoid confusion. After Feil's thesis, because of the broad and heterogeneous categorization, there was still usefulness in clarifying and detailing the classification for Klippel-Feil syndrome patients. In his thesis Feil included in the Type III category reductions in the number of parts of the spine other than cervical and other numerical spinal anomalies (Table 2). ${ }^{22}$ On the other hand, if Klippel-Feil syndrome is referred to as in the 1912 paper, then it describes only a severe degree of spinal malformation (patient L. Joseph-Type I).

Perhaps the term Klippel-Feil syndrome should be used to refer to the clinical triad described originally in the 1912 article and as described in Feil's thesis. We cannot deny that the transition from the numerical reduction of the cervical vertebrae to vertebral fusion was the correct way to condense and clarify the definition of the term; however, perhaps anatomically, this fusion should be defined only as Klippel-Feil anomaly. The diagnosis of 
TABLE 2. Original description of classification of reduction of the number of cervical vertebrae, described by A. Feil in his thesis*

\begin{tabular}{|c|c|}
\hline Type & Description \\
\hline Type I & $\begin{array}{l}\text { It is the type that can be isolated best. Lesions are only in the cervical column. The rest of the spinal column is completely normal. Maximal } \\
\text { reduction of the number of vertebrae. The cervical vertebrae seem absent or very reduced; remnant ribs constitute a true cervical thorax; } \\
\text { there is a posterior triangular orifice that we assume is a superior cervical spina bifida, basilar kyphosis-straight descent almost vertical } \\
\text { from the posterior fossa, referred by Wirchow [Virchow] as Basilew-impression [basilar impression]. }\end{array}$ \\
\hline Type II & $\begin{array}{l}\text { The reduction is limited to } 1 \text { or } 2 \text { cervical vertebrae. Along with this less-involved anatomical abnormality, one will observe an attenuation } \\
\text { of symptomatology. Groups of observations transition between the normal and the Type I. This group comprises complex morphological } \\
\text { disorders such as fusion, hemivertebrae, and occipitalization of the atlas. Anatomically, reduction of } 1 \text { or } 2 \text { vertebrae. Clinically is veiled. } \\
\text { Low hairline is rare. Motion restriction is variable. }\end{array}$ \\
\hline Type III & $\begin{array}{l}\text { There is compression or a numeric reduction of cervical vertebrae, just like in the previous groups; however, the lesions are not confined to } \\
\text { the cervical column. They can be found throughout the spine. This spread leads to a less clearly defined clinical syndrome. These impor- } \\
\text { tant congenital anomalies are hardly compatible with life. They are, therefore, typically seen in the fetus or neonate. }\end{array}$ \\
\hline
\end{tabular}

* Translation from Feil, 1919.

Klippel-Feil syndrome is primarily based on radiological findings and therefore should be called an anomaly. These radiological findings should be named with anatomical terminology, as proposed initially by Bertolotti: occipitalization of the atlas, ankyloses of the atlas with the occipital bone, deformities of the skull bones, assimilation of the third cervical vertebra and axis, transverse segmentation of the vertebral bodies, vertical segmentation of vertebral bodies, basal segmentation of the odontoid process, and hemispondylia. ${ }^{49}$

Additionally, we should take into account that Feil based his classification on 14 cases, 13 of which, it appears, he did not examine personally. Feil's descriptive classification had some small predictive value, and it was used to distinguish more pronounced cases from vague cases. At that time, of course, there was no MRI or CT to reveal asymptomatic cases, and radiography was not systematically performed or inspected to catch such diagnoses. In this view, classifications should be clinically relevant and targeted toward answering questions about possible prognosis, complications, and inheritance. With this in mind, Clarke et al..$^{14}$ conducted a thorough cytogenetic study of three families with Klippel-Feil syndrome and proposed a new classification. This classification (Table 3 ) delineates four classes based on the different vertebral fusion processes, morphologies and positions, associated abnormalities, and, most importantly, different modes of inheritance. When classifications of this syndrome are used, it should be referred to in the following way based on which method was used: Feil's classification (1912) of the Klippel-Feil syndrome, Samartzis's (2006) radiological classification of Klippel-Feil syndrome, or Clarke's heterogeneity classification of Klippel-Feil syndrome into 4 classes (1998). Recent studies continue to reveal new genetic variants in signaling molecules that play roles in the development of the vertebral column and that may lead to the formation of Klippel-Feil anomaly. ${ }^{38}$

\section{André Feil's Other Works}

Through the early to mid-1920s, Feil continued to publish on various cases of congenital malformations. He published several articles recounting and elaborating on the L. Joseph case and other musculoskeletal anoma- lies, ${ }^{17-21,23,25}$ documenting and analyzing patients who presented with congenital lack of the ulna, absence of the pectoralis major muscle, brachydactyly, and other malformations. In 1923, Feil published an article entitled "Role des traumatismes et des tentatives d'avortment dans la formation des anomalies et des monstres" (Role of trauma and attempted abortion in the formation of anomalies and monsters $)^{24}$ that criticized two commonly held reasons for congenital malformations: minor trauma and the woman's imagination during her pregnancy. Feil stated, "These two causes: trauma [and] role of imagination [are] enough to satisfy the minds of people, even educated, yet who think themselves freed from superstitious ideas; or what woman during her pregnancy, did not experience fear or received a sudden blow?...Let's not even deal with the role of the imagination as it has no serious basis, but with the trauma which is a more reasonable issue." Traumas of a severe nature induced on a developing fetus, such as those observed with attempted abortion, Feil acknowledged, could "act on the seed, producing a monstrosity." However, Feil believed violent traumas would be more likely to cause an abortion or premature birth, as opposed to a defect in fetal development.

Toward the end of his career, Feil took an interest in illnesses associated with occupational settings, in particular, pneumoconiosis. ${ }^{33,34} \mathrm{He}$ was a prolific author on conditions affecting the human condition and on public health, continuing to publish with Klippel into the $1920 \mathrm{~s} .{ }^{42}$ However, it was his early work on congenital abnormalities, influenced by Klippel, one of the foremost medical mentors of the time, that helped alter literally centuries of unsubstantiated beliefs affecting such patients.

\section{Conclusions}

Over the course of his life, Feil's work transcended the importance of merely reporting on congenital malformations by playing an integral role in the socioscientific transformation of attitudes toward patients. During a time in which Western society continued to blame human deformities on atavistic or ontological origins, Feil was a pioneer in rejecting such theories and setting forth a new path for understanding the underlying mechanisms at work in congenital abnormalities. It is clear through his 
TABLE 3. Classifications of Klippel-Feil syndrome

\begin{tabular}{|c|c|c|c|c|}
\hline \multicolumn{4}{|c|}{ Classification by Clarke et al. ${ }^{*}$} & \multirow{2}{*}{ 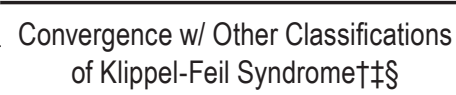 } \\
\hline Class & Radiological \& Clinical Features & Associated Anomalies & Probable Inheritance & \\
\hline Class 1 & $\begin{array}{l}\text { Occiput-C1 \&/or C1-2 fusion, } \\
\text { may also have fusions at other } \\
\text { cervical levels, present at birth, } \\
\text { classic phenotypic Klippel-Feil } \\
\text { triad (common) }\end{array}$ & $\begin{array}{l}\text { Short neck; variable defects: } \\
\text { auditory, cardiac, craniofacial, } \\
\text { microcephaly, myopathy, ocu- } \\
\text { lar, skeletal, urogenital }\end{array}$ & AR & $\begin{array}{l}\text { Types I, II, \& III;† Types 1, 2, \& 3; } \\
\text { occipitoatlantal fusion;§ Klippel-Feil } \\
\text { syndrome-4 AR caused by muta- } \\
\text { tion in the MYO18B gene (OMIM } \\
\text { \#616549) }\end{array}$ \\
\hline Class 2 & $\begin{array}{l}\text { C2-3 fusion, no fusion above C-2, } \\
\text { may have cervical, thoracic, \&/ } \\
\text { or lumbar fusions, apparent } \\
\text { postnatally, classic phenotypic } \\
\text { triad (rare) }\end{array}$ & $\begin{array}{l}\text { Variable defects: auditory, cranio- } \\
\text { facial, high scapula (Sprengel } \\
\text { anomaly), skeletal; accentuated } \\
\text { effects of trauma, osteoarthritis, } \\
\text { basilar impression }\end{array}$ & $A D$ & $\begin{array}{l}\text { Types I, II, \& III;† Types 1, 2, \& 3; } \\
\text { familial C2-3 fusion;§ familial C5-6 } \\
\text { fusion;§ variable cervical fusion; } \S \\
\text { Klippel-Feil syndrome-1 AD caused } \\
\text { by mutation in the GDF6 gene } \\
\text { (OMIM \#118100) }\end{array}$ \\
\hline Class 3 & $\begin{array}{l}\text { Single fusion at variable levels, no } \\
\text { C1-2 fusion }\end{array}$ & $\begin{array}{l}\text { Facial dysmorphology; variable } \\
\text { defects: auditory, cardiac, } \\
\text { craniofacial, ocular, skeletal }\end{array}$ & $A R, A D$ & $\begin{array}{l}\text { Type Il; } † \text { Types } 1 \& 2 ; \ddagger \text { familial C5-6 } \\
\text { fusion; } \S \text { variable cervical fusion; } \S \\
\text { Klippel-Feil syndrome-2 AR caused } \\
\text { by mutation in the MEOX1 gene } \\
\text { (OMIM \#214300); Klippel-Feil syn- } \\
\text { drome-3 AD caused by mutation in } \\
\text { the GDF3 gene (OMIM \#613702) }\end{array}$ \\
\hline Class 4 & $\begin{array}{l}\text { Fusion of } 1 \text { or more cervical } \\
\text { vertebrae, abducens nerve } \\
\text { palsy w/ globe retraction (Duane } \\
\text { syndrome), hearing loss, present } \\
\text { at birth }\end{array}$ & $\begin{array}{l}\text { Variable defects: cardiac, Chiari } \\
\text { malformation, craniofacial, } \\
\text { skeletal }\end{array}$ & $\begin{array}{l}\text { Affects females primarily; } \\
\text { may be X-linked, w/ } \\
\text { incomplete penetrance } \\
\text { \& variable expressivity }\end{array}$ & $\begin{array}{l}\text { Wildervanck syndrome (cervicoocu- } \\
\text { loacoustic syndrome) }\end{array}$ \\
\hline
\end{tabular}

$\mathrm{AD}=$ autosomal dominant; $\mathrm{AR}=$ autosomal recessive; $\mathrm{OMIM}=$ Online Mendelian Inheritance in Man.

* Data compiled from Clarke et al., 1998.

† Feil, 1919.

$\ddagger$ Samartzis et al., 2006.

$\S$ Gunderson et al., 1967.

initial research on congenital malformations and occupational health risks later in life that he had a deep desire to improve the lives of those around him. In addition to practicing the science of medicine, he highlighted the importance of humanism to medicine, and we have inherited his legacy for care and consideration for those we might term "handicapped." Although his name is not often encountered in the annals of history, there is no denying that Feil played a critical role in attempting to change a sociocultural mind-set rooted in ignorance and fear. His interest was largely stimulated by his mentor Klippel and his interaction with one patient who had a spinal abnormality-L. Joseph.

\section{Acknowledgments}

We thank the Neuroscience Publications staff at Barrow Neurological Institute, Phoenix, Arizona, for their assistance. We thank Nicole Rose Galvan, library technician, and Gleb Zhdanovich, $\mathrm{MD}$, for assistance with finding and digitizing the old texts. This research was supported with funds from the Barrow Neurological Foundation, the Women's Board of the Barrow Neurological Institute, and in part by the Newsome Family Endowment in Neurosurgery to Dr. Preul. Dr. Belykh is supported by scholarship (SP156.2013.4) funds from the Council of the President of the Russian Federation for grants in support of young Russian scientists. Drs. Belykh and Lei are supported by funds from the Barrow Neurological Foundation. Dr. Byvaltsev is supported by funds from the Russian Science Foundation (Project 15-15-30037).

\section{References}

1. AF: Biographie du Docteur Maurice Klippel. Le Rictus 9:9-10, 1913

2. Alexander of Hales: Summa Universis Theologiae. Rome: Collegii S. Bonaventurae, 1924-1948

3. Barnard H: Sire, il n'y a pas de Blemmyes: a re-evaluation of historical and archaeological data, in Starkey JCM (ed): People of the Red Sea. Oxford, UK: Archaeopress, 2005

4. Barrow MV: A brief history of teratology to the early 20th century. Teratology 4:119-129, 1971

5. Bates AW: Emblematic Monsters: Unnatural Conceptions and Deformed Births in Early Modern Europe. Wellcome Series in the History of Medicine. Amsterdam: Rodopi, 2005

6. Bauhin C: De Hermaphroditorum Monstrosorumque Partuum Natura ex Theologorum, Jureconsultorum, Medicorum, Philosophorum, \& Rabbinorum Sententia. Oppenheim: Galleri \& Bry, 1600

7. Béclard M: Mémoire sur les foetus acephalés. Paris: Migneret, 1818

8. Bertolotti M: Contributo alla conoscenza dei vizi differenzazione regionale del rachide con speciale riguardo all assimilazione sacrale della V. lombare. Radiol Med (Torino) 4:113-144, 1917

9. Bertolotti M: Le anomalie congenite del rachide cervicale. Chir Organi Mov 4:395, 1920

10. Boaistuau P: Histoires prodigieuses (èdition de 1561): èdition critique. Cèard J, Bamforth S (eds). Geneva: Droz, 2010

11. Bouchard F: Infante monstroso Lugduni in viam publicam 
die V. Martii A. MDCLXXI. exposito. Miscellanea Curiosa 3:14-16, 1672

12. Bourdier F: Geoffroy Saint-Hilaire Étienne. Complete Dictionary of Scientific Biography. (http://www. encyclopedia.com/topic/etienne_Geoffroy_Saint-Hilaire. aspx\#1-1G2:2830901617-full) [Accessed April 29, 2016]

13. Capella MMF: De nuptiis philologiae et Mercurii: de gramatica; de dialectica; de rhetorica; de geometria; de arithmetica; de astronomia; de musica. Bodianus FV (ed). Vicenza: Henricus De Sancto Ursio, 1499

14. Clarke RA, Catalan G, Diwan AD, Kearsley JH:

Heterogeneity in Klippel-Feil syndrome: a new classification. Pediatr Radiol 28:967-974, 1998

15. Dareste C: Recherches sur la production artificielle des monstruosités, ou, Essais de tératogénie expérimentale. Paris: E. Reinwald, 1877

16. Dreuille R: Pierre Delbert. Whonamedit? (http://www. whonamedit.com/doctor.cfm/1936.html) [Accessed May 2, 2016]

17. Feil A: Anatomie du vivant. Absence du muscle grand pectoral. Presse Med 81:1705, 1924

18. Feil A: Anatomie du vivant. Brachydactylie par absence des phalangines. Presse Med 69:1451, 1924

19. Feil A: Anatomie du vivant. Ectrodactylie. Presse Med 63:1337, 1924

20. Feil A: Anatomie du vivant. Phocomelie. Presse Med 99:2090, 1924

21. Feil A: Faits Cliniques. Sur la localization du spina-bifida dans la region cervicale. Progr Med (Paris) 1:510-511, 1920

22. Feil A: L'absence et la diminution des vertèbres cervicales [thesis]. Paris: Faculté de Médicine, 1919

23. Feil A: Occipitalization de l'atlas et torticollis congenital. Presse Med 52:515, 1924

24. Feil A: Role des traumatismes et des tentatives d'avortment dans la formation des anomalies et des monstres. Paris Med (Paris) 47:559-562, 1923

25. Feil A: Travaux originaux. Sacralization de la V lombaire et nevralgie sciatique. Progr Med (Paris) 13:134-135, 1921

26. Fenton E: Certaine Secrete Wonders of Nature. London: Bynneman, 1569

27. Friedman JB: The Monstrous Races in Medieval Art and Thought. Syracuse, NY: Syracuse University Press, 2000

28. Geoffroy Saint-Hilaire E: Philosophie anatomique. Paris: JB Baillière, 1818

29. Goodhart J: Description of three cases of malformation of the spinal column associated with lateral curvature. J Anat Physiol 9:1-16, 1874

30. Guérin J: Recherches sur les difformités congénitales: chez les monstres, le fotus et l'enfant. Paris: Bureau de la publication, 1880

31. Gunderson CH, Greenspan RH, Glaser GH, Lubs HA: The Klippel-Feil syndrome: genetic and clinical reevaluation of cervical fusion. Medicine (Baltimore) 46:491-512, 1967

32. Hayem G: Revue des sciences médicales en France et à l'étranger. Paris: Masson, 1873

33. Heim de Balsac F, Agasse-Lafont E, Feil A: Les risques actuels d'arsenicisme professionnel dans certaines branches de l'industrie chimique. Paris: Masson, 1927

34. Heim de Balsac F, Feil A: Vernis cellulosiques et peinture au pistolet. Enquête sur l'état sanitaire des ouvriers peintres au pistolet. Paris: Masson, 1932

35. Herodotus: The History. Grene D (ed). Chicago: University of Chicago Press, 1987

36. Isidore of Seville: The Etymologies of Isidore of Seville. Barney SA (ed). Cambridge: Cambridge University Press, 2006

37. James MR (ed): Marvels of the East: a Full Reproduction of the Three Known Copies. Oxford: Oxford University Press, 1929

38. Karaca E, Yuregir OO, Bozdogan ST, Aslan H, Pehlivan $\mathrm{D}$, Jhangiani SN, et al: Rare variants in the notch signaling pathway describe a novel type of autosomal recessive Klippel-Feil syndrome. Am J Med Genet A 167A:27952799, 2015

39. Kieffer C: Sacrifice of the social outcasts: two cases of Klippel-Feil syndrome at Midnight Terror Cave, Belize. Int J Osteoarchaeol [epub ahead of print], 2015

40. Klippel M, Feil A: Anomalie de la colonne vertebrale par l'absence des vertebres cervicales: cage thoracique remonant jusqu'a la base du crane. Bull Mem Soc Anat Paris 87:185188,1912

41. Klippel M, Feil A: The classic: A case of absence of cervical vertebrae with the thoracic cage rising to the base of the cranium (cervical thoracic cage). Clin Orthop Relat Res (109):3-8, 1975

42. Klippel M, Feil A: Les perforations typhiques peucent-elles guerir sans peritonite et sans intervention? Presse Med 65:697-698, 1922

43. Klippel M, Feil A: Un cas d'absence des vertébres cervicales cage thoracique remontant jusqu'a la base du crâne. Bull Mém Soc Anthrop Paris 3:101-102, 1912

44. Le Lorier MV, Dupont R: Méningocèle et malformations multiples. Bull Mém Soc Anthrop Paris 86:68, 1911

45. Leonardi M: A history of neuroradiology in Italy. AJNR Am J Neuroradiol 17:721-730, 1996

46. Liceti F, Blasius GL: De Monstrorum Natura, Causis, et Differentiis. Padua: Apud Paulum Frambottum, 1634 (Latin)

47. Mattirolo G, Bertolotti M: [On a rare malformation of the cephalic end of the vertebral column.] Gior R Accad Med Torino 83:3, 1920 (Ital)

48. McLaughlin MM, Ross JB: The Portable Renaissance Reader. New York: Viking Penguin, 1981

49. Medical Research Council: Medical Science Abstracts and Reviews, Vol 4. London: Oxford University Press, 1921

50. Meisenbach RO: Absence of the cervical spine; report of a case. Am J Orthop Surg 210:647-648, 1913

51. Morgagni JB: De Sedibus et Causis Morborum per Anatomen Indagatis. Chaussier F, Adelon NP (eds). Paris: MC Compère, 1820

52. Morgagni JB: XLVIII Lettre anatomico-medicale. De la fausse grossesse, de l'avortment, de l'accouchement malheureux, in Recherches anatomiques sur le siege et les causes des maladies. Paris: Adolphe Delahays, 1855

53. Nau P: Les scolioses congenitales. Paris: Jules Rousset, 1904

54. Nikkhah R: Real-life Quasimodo uncovered in Tate archives. Daily Telegraph. August 15, 2010. (http://www.telegraph.co.uk/culture/books/ artsandentertainmentbooksreview/7945634/Real-lifeQuasimodo-uncovered-in-Tate-archives.html) [Accessed April 27, 2016]

55. Paré A: On Monsters and Marvels. Pallister JL (trans). Chicago: University of Chicago Press, 1982

56. Park K, Daston LJ: Unnatural conceptions: the study of monsters in sixteenth- and seventeenth-century France and England. Past Present 92:20-54, 1981

57. Patel PR, Lauerman WC: Maurice Klippel. Spine (Phila Pa 1976) 20:2157-2160, 1995

58. Pliny: The Natural History of Pliny. Bostock J, Riley HT (eds). London: HG Bohn, 1855

59. Romer FE: Pomponius Mela's Description of the World. Ann Arbor: University of Michigan Press, 1998

60. Ryrie CC (ed): Moses: The Book of Genesis 9:20-27, in Ryrie Study Bible, King James Version. Chicago: The Moody Bible Institute, 1994

61. Samartzis D, Herman J, Lubicky JP, Shen FH: Classification of congenitally fused cervical patterns in Klippel-Feil patients: epidemiology and role in the development of cervical spine-related symptoms. Spine (Phila Pa 1976) 31:E798-E804, 2006 
62. Samartzis D, Herman J, Lubicky JP, Shen FH: Sprengel's deformity in Klippel-Feil syndrome. Spine (Phila Pa 1976) 32:E512-E516, 2007

63. Shakespeare W: Othello. With Introduction, Notes, and Plan of Preparation. Kellog B (ed). New York: Maynard, Merrill, \& Co, 1891

64. Shakespeare W: The Tempest: With Introduction, and Notes Explanatory and Critical. For Use in Schools and Classes. Hudson HN (ed). Boston: Ginn \& Co, 1890

65. Shelley MW: Frankenstein; or, The Modern Prometheus. London: Lackington, Hughes, Harding, Mavor, and Jones, 1818

66. Steinheil G (ed): Bulletins et Mémoires de la Société Anatomique de Paris, 1911. Paris: Société Anatomique de Paris, 1911

67. Theiss SM, Smith MD, Winter RB: The long-term followup of patients with Klippel-Feil syndrome and congenital scoliosis. Spine (Phila Pa 1976) 22:1219-1222, 1997

68. Tilley L, Oxenham MF: Survival against the odds: Modeling the social implications of care provision to seriously disabled individuals. Int J Paleopathology 1:35-42, 2011

69. Tracy MR, Dormans JP, Kusumi K: Klippel-Feil syndrome: clinical features and current understanding of etiology. Clin Orthop Relat Res (424): 183-190, 2004

70. Ward AW, Waller AR (eds): The Cambridge History of English Literature, Vol 9. From Steele and Addison to Pope and Swift. Cambridge: Cambridge University Press, 1912

71. Willett A, Walsham WJ: An account of the dissection of the parts removed after death from the body of a woman the subject of congenital malformation of the spinal column, bony thorax, and left scapular arch; with remarks on the probable nature of the defects in development producing the deformities. Med Chir Trans 63:257-302, 302.1-302.3, 1880
72. Wilson DB: Signs and Portents: Monstrous Births from the Middle Ages to the Enlightenment. London: Routledge, 1993

73. Yentis SM, Hirsch NP, Ip JK: Anaesthesia and Intensive Care A-Z: An Encyclopedia of Principles and Practice. London: Churchill Livingstone Elsevier, 2013

\section{Disclosures}

The authors report no conflict of interest concerning the materials or methods used in this study or the findings specified in this paper.

\section{Author Contributions}

Conception and design: Preul, Belykh, Byvaltsev, Theodore. Acquisition of data: Preul, Belykh, Malik, Simoneau, Cavalcanti. Analysis and interpretation of data: Preul, Belykh, Malik, Simoneau, Lei. Drafting the article: Belykh, Malik, Simoneau, Lei. Critically revising the article: Preul, Belykh, Byvaltsev, Theodore. Reviewed submitted version of manuscript: all authors. Approved the final version of the manuscript on behalf of all authors: Preul. Statistical analysis: Belykh. Administrative/ technical/material support: Preul, Byvaltsev, Theodore. Study supervision: Preul.

\section{Correspondence}

Mark C. Preul, c/o Neuroscience Publications, Barrow Neurological Institute, St. Joseph's Hospital and Medical Center, 350 W Thomas Rd., Phoenix, AZ 85013.email: neuropub@ dignityhealth.org. 